University of Tennessee Law

Legal Scholarship Repository: A Service of the Joel A. Katz Library

UTK Law Faculty Publications

2020

Parens Patriae and the Disinherited Child

Michael J. Higdon

Follow this and additional works at: https://ir.law.utk.edu/utklaw_facpubs

Part of the Law Commons 


\section{University of Tennessee College of Law}

From the SelectedWorks of Michael J Higdon

2020

\section{Parens Patriae and the Disinherited Child}

Michael J Higdon 


\title{
PARENS PATRIAE AND THE DISINHERITED CHILD
}

\author{
Michael J. Higdon*
}

Abstract: Most countries have safeguards in place to protect children from disinheritance. The United States is not one of them. Since its founding, America has clung tightly to the ideal of testamentary freedom, refusing to erect any barriers to a testator's ability to disinherit his or her children-regardless of the child's age or financial needs. Over the years, however, disinheritance has become more common given the evolving American family, specifically the increased incidences of divorce, remarriage, and cohabitation. Critics of the American approach have offered up reforms based largely on the two models currently employed by other countries: (1) the forced heirship approach, in which all children are entitled to a set percentage of their parent's estate; and (2) family maintenance statutes, which provide judges with the discretionary authority to override a testator's wishes and instead award some portion of the estate to the testator's surviving family members. This Article takes a different approach and looks at the issue of disinheritance through a new lens: the doctrine of parens patriae. Just as this doctrine limits the decision-making autonomy of living parents vis-à-vis their children, this Article argues that it should likewise limit the dead hand control of deceased parents. Focusing on minor children, adult children who remain dependent as a result of disability, and adult children who are survivors of parental abuse, it is the contention of this Article that testamentary freedom must sometimes yield to the state's inherent parens patriae authority to protect children from harm. Specifically, this Article proposes that courts must refuse enforcement of testamentary schemes that disinherit children who fall into those categories if that disinheritance would constitute abuse or neglect. Such an approach is not only mandated by the doctrine of parens patriae but, in contrast to the approaches other countries have adopted, is much more deferential to testamentary freedom. The limitations imposed by this proposal represent a relatively modest curtailment of the rights testators currently possess and, at the same time, are consistent with existing exceptions to testamentary freedom, most notably those in place to protect spouses and creditors as well as those that prohibit the enforcement of testamentary provisions that violate public policy.

INTRODUCTION 620

I. DISINHERITANCE AND THE DEAD HAND .............. 627

A. The United States Approach ....................................... 631

B. International Approaches ……………………….........636 636

1. Forced Heirships .................................................. 637

2. Family Maintenance Statutes …………………..... 639

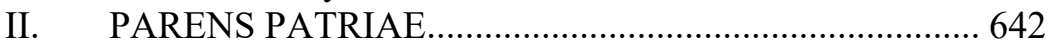

A. A Brief History …………............................................... 643

B. Usage in Contemporary Family Law .......................... 647

III. WHEN DISINHERITANCE BECOMES A FORM OF ABUSE OR NEGLECT .................................................. 651

* Professor of Law, University of Tennessee College of Law. A special thank you to Allison Tait, Alex Boni-Saenz, Andrew Gilden, Ayelet Blecher, and Jill Hasday for their incredibly helpful feedback. Additionally, I am grateful to the University of Tennessee College of Law, particularly Dean Melanie Wilson, for providing generous financial support for this project. 
A. Vulnerable Child Heirs and the Evolving Family ..... 652

1. Minor Children....................................................... 655

2. Adult Children Who Remain Dependent Due to Disability

3. Adult Survivors of Child Abuse.

B. Parens Patriae Protects Vulnerable Child Heirs Without Unduly Restricting Testamentary Freedom. 661

1. Preserving Testamentary Freedom....................... 662

2. Promoting Consistency with Current Exceptions 663

IV. INCORPORATING PARENS PATRIAE INTO

THE LAW OF DISINHERITANCE 667

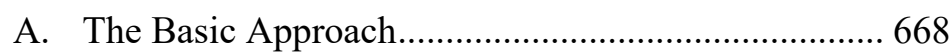

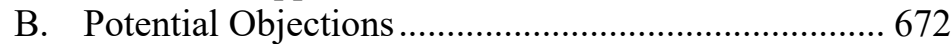

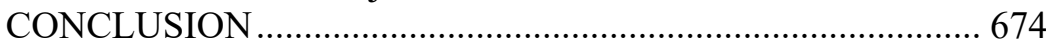

\section{INTRODUCTION}

"[W]hen it comes to inheritance,

American children are in need of a champion."

In 2013, J.C. Cole died leaving behind an estate valued at $\$ 15$ million. $^{2}$ Two days before he died, J.C. executed a will that disinherited his only child, Karla: "It is my intention to make no provision in this Will for [Karla] or her heirs, whom I have no relationship with in the past or at this time." In an attempt to have the will set aside, Karla brought suit claiming that her father had sexually abused her as a child, and after confronting him about the abuse as an adult, he retaliated by writing her out of the will. ${ }^{4}$ Karla argued that her father's will violated public policyspecifically, the state's "clear, unequivocal, and unbending ... hostility toward sexual abuse of minors." Karla's factual allegations were "vigorously disputed," but ultimately the facts would be of no consequence given that the Texas court dismissed her complaint as having no basis in law. The court did so by noting that state law "confer[s] upon

1. Deborah A. Batts, I Didn't Ask to Be Born: The American Law of Disinheritance and A Proposal for Change to A System of Protected Inheritance, 41 HASTINGS L.J. 1197, 1197 (1990).

2. Merrick v. Helter, 500 S.W.3d 671, 672 n.1 (Tex. App. 2016).

3. Id. at 674 .

4. Id. at 672 .

5. Id. at 674 (internal quotation marks omitted).

6. Id. at 672. The executor "asserted not only a general denial but also [alleged that Karla] had filed a false and groundless pleading knowingly in an attempt to harass, intimidate, and 'defraud' [the executor] into abandoning the probate proceedings." Id. 
the testator full power freely to make any disposition he desire[s] to make of his property," and "whether he exercised the right he possessed wisely or unwisely, justly or unjustly, is not for the courts to determine."7 Thus, according to the court, Karla's father was free to disinherit her even if that disinheritance stemmed from his sexual abuse of her as a child.

The ruling in Karla's case is not the product of some idiosyncratic Texas law, but instead is emblematic of the American approach to succession in general. In forty-nine states, parents have the right "to disinherit their children and grandchildren for any reason or no reason"8 a right that has existed since the country's founding. ${ }^{9}$ Although early legal philosophers, most notable of whom was John Locke, would take the position that inheritance was a natural right, ${ }^{10}$ others advocated for a more positivistic approach. Blackstone, for instance, wrote in his Commentaries that inheritance was "no natural, but merely a civil right," cautioning that "we [not] mistake for nature what we find established by long and inveterate custom." 11 By the time the United States came into existence, the positivistic approach had prevailed and ever since has "dominated this country's thinking on inheritance." 12 In 1898, the Supreme Court would declare that "[t]he right to take property by devise or descent is the creature of the law, and not a natural right." ${ }^{, 13}$

It is against that backdrop that American inheritance law has evolved into a system that is "without parallel elsewhere in the western world"14 one that prioritizes testamentary freedom even at the expense of a testator's children. In the United States today, a testator "can disinherit minor, disabled, and unborn children without cause or remedy." 15 As other

7. Id. at 675 (quoting Perry v. Rogers, 114 S.W. 897, 898 (Tex. Civ. App. 1908)).

8. Joshua C. Tate, Caregiving and the Case for Testamentary Freedom, 42 U.C. DAVIS L. REV. 129,131 (2008). Louisiana is the one state that does have some protections for children, but even they are quite limited. See infra notes $147-153$ and accompanying text.

9. See infra notes 89-92 and accompanying text.

10. Jacqueline Asadorian, Disinheritance of Minor Children: A Proposal to Amend the Uniform Probate Code, 31 B.C. THIRD WORLD L.J. 101, 101 (2011) ("God Planted in Men a strong desire ... of propagating their Kind, and continuing themselves in their Posterity, and this gives Children a Title, to share in the Property of their Parents, and a Right to Inherit their Possessions.") (quoting JOHN Locke, Two Treatises OF GOVERnMENT 206-07 (Peter Laslett ed., Cambridge Univ. Press 1988) (1690)).

11. 2 William BlacKstone, COMMENTARIES $* 11$.

12. Mark L. Ascher, Curtailing Inherited Wealth, 89 MICH. L. REV. 69, 77 (1990); see also Stanley N. Katz, Republicanism and the Law of Inheritance in the American Revolutionary Era, 76 MICH. L. REV. 1, 8 (1977-1978) ("American state and federal courts since the foundation of the new nation have been equally committed to the positivist argument.").

13. Magoun v. Ill. Tr. \& Sav. Bank, 170 U.S. 283, 288 (1898).

14. Adam J. Hirsch, American History of Inheritance Law, in 3 OXFORD INTERNATIONAL ENCYCLOPEDIA OF LEGAL HiSTORY 239 (Stanley N. Katz ed. 2009).

15. Frances H. Foster, Linking Support and Inheritance: A New Model from China, 1999 WIS. L. REV. 1199, 1217-18 (1999). 
commentators have noted, "even a wealthy parent is permitted to leave his needy children penniless" 16 and instead devise the entire estate to "collateral relatives, friends, or charity." 17 Very few countries permit testamentary freedom to extend this far - a fact Ralph Brashier noted twenty-five years ago: "Perhaps more than any other civilized people, Americans cling to and zealously guard this freedom, even while other common law countries have increasingly recognized a posthumous obligation to support needy family members." ${ }^{18}$ Today, most civilized countries - even England, from which American succession laws are derived-have safeguards in place to protect children from disinheritance, ${ }^{19}$ making the United Sates "almost alone in the modern world." 20

That the United States would take such an approach is somewhat surprising given its general insistence that parents protect and provide for their children. ${ }^{21}$ For example, whereas every state requires parents to support their children during the child's minority, ${ }^{22}$ succession laws permit a parent to disinherit a child of any age. Additionally, although states require parents to support adult children who remain dependent due to a disability, ${ }^{23}$ a parent can execute a will ensuring that any such obligation terminates with the parent's death, effectively shifting the financial responsibility to the state. ${ }^{24}$ Finally, as the case that began this Article suggests, even children who were abused by a parent and, as a result suffer physical; psychological; and financial harm, ${ }^{25}$ can still be disinherited despite the states' interest in protecting abused children. ${ }^{26}$

16. Ralph C. Brashier, Protecting the Child from Disinheritance: Must Louisiana Stand Alone, 57 LA. L. REV. 1, 3 (1996) [hereinafter Brashier, Protecting the Child].

17. Ascher, supra note 12 , at 80 .

18. Ralph C. Brashier, Disinheritance and the Modern Family, 45 CASE W. RES. L. REV. 83, 172 (1994) [hereinafter Brashier, Modern Family].

19. See infra section I.B.

20. Ronald Chester, Disinheritance and the American Child: An Alternative from British Columbia, 1998 UTAH L. REV. 1, 24 (1998).

21. See, e.g., L.M. v. R.L.R., 888 N.E.2d 934, 937 (Mass. 2008) (noting that "[t]he law has long imposed a duty on parents to support, provide for and protect the children they bring forth") (internal quotation marks omitted); Tom Stacy, Acts, Omissions, and the Necessity of Killing Innocents, 29 AM. J. CRIM. L. 481, 495 (2002) ("The parent/child relationship is the paradigmatic special relationship, imposing duties on parents to take action to protect their child's basic welfare.").

22. See Jacqueline Asadorian, Disinheritance of Minor Children: A Proposal to Amend the Uniform Probate Code, 31 B.C. THIRD WORLD L.J. 101, 103 (2011).

23. See infra note 286 and accompanying text.

24. See Asadorian, supra note 22, at 103 ("[W] hen a parent is unwilling or unable to provide for a child, the state must step in and provide support.").

25. See infra notes 300-305 and accompanying text.

26. See Maryland v. Craig, 497 U.S. 836, 853 (1990) (noting the "[s]tate's interest in the physical and psychological well-being of child abuse victims"). 
Thus, as Deborah Batts summarizes, "the parental obligation to nurture, support, educate, and provide for the child . . . . is consistently abandoned whenever it clashes with another fundamental concept imbedded in America's social and legal structure: testamentary freedom.,"27

Despite that longstanding approach, it is the basic contention of this Article that reform has become increasingly necessary. First, with the increased incidences of divorce, marriage, and cohabitation, ${ }^{28}$ American children today are much more susceptible to parental disinheritance. ${ }^{29}$ As other scholars have noted, the children most likely to be disinherited are those "whose parents are divorced, those born out of wedlock, and particularly those children with a non-custodial parent who ha[ve] started a new family." ${ }^{30}$ More importantly, reform is necessary because disinheritance can be extremely devastating to particular classes of children. Thus, as more parents fail to provide for their children at death, some of the states' most vulnerable citizens are now at an even greater risk of harm at the hands of their parents. For those reasons, the time has come for the law to reconsider the expansive freedom it has extended to parent testators to disinherit their children.

Although other legal scholars have criticized the American tolerance for child disinheritance, the solutions they have put forth have largely involved adopting some combination of the two approaches currently employed by the countries that do protect children from disinheritance: forced heirship and family maintenance statutes. ${ }^{31}$ It is the position of this Article, however, that the answer lies, not in the law of succession, but in the law of domestic relations - specifically, the doctrine of parens patriae. This doctrine confers upon courts both the power and the duty to protect children from abuse or neglect: "Parens patriae, literally 'parent of the country,' is the government's power and responsibility, beyond its police

\section{Batts, supra note 1, at 1197.}

28. See Michael J. Higdon, Constitutional Parenthood, 103 IowA L. REV. 1483, 1487 (discussing how "issues of parenthood have ... become more complicated through the rise in both divorce and nonmarital cohabitation"); infra notes 256-263 and accompanying text.

29. See Brashier, Protecting the Child, supra note 16, at 11 ("Children of divorce and nonmarital children are particularly likely to bear the brunt of disinheritance.”).

30. See Asadorian, supra note 22, at 121.

31. See, e.g., Asadorian, supra note 22 (advocating for a forced heirship approach); Paul G. Haskell, The Power of Inheritance, 52 GEO. L.J. 499, 519 (same); Brashier, Protecting the Child, supra note 16, at 24 (suggesting an "intermediate system" that borrows from both the forced heirship and the family maintenance approaches); Chester, supra note 20 (advocating for a family maintenance approach similar to the one used in British Columbia); Foster, supra note 15 at 1207 (pointing to China's forced heirship model in order to "highlight[] the inequities of the American system on an individual level and the need for a more flexible, responsive approach to inheritance"); Phyllis C. Taite, Freedom of Disposition v. Duty of Support: What's a Child Worth?, 2019 WISC. L. REV. 325 (advocating for a forced share for minor children and an elective share for adult children). For more on the two systems, see infra section I.B. 
power over all citizens, to protect, care for, and control citizens who cannot take care of themselves." 32 And pursuant to this doctrine, the government's power vis-à-vis parents is considerable. Lewis Hochheimer in his famous treatise on children described the relationship as follows: "[A]ll power and authority over infants are a mere delegated function entrusted by the sovereign state to the individual parent or guardian, revocable by the state through its tribunals, and to be at all times exercised in subordination to the paramount and overruling direction of the state." ${ }^{33}$

Looking at the problem of child disinheritance through the lens of parens patriae, this Article argues that, just as parents' rights to direct the upbringing of their children must sometimes yield to the states' overriding interest in protecting children, so too are there instances of attempted child disinheritance where testamentary freedom must likewise give way to those same interests. Namely, when confronted with situations in which a testator's attempted disinheritance would subject a child to conditions amounting to abuse or neglect, the state must intervene in its role as "protector of vulnerable parties" ${ }^{34}$ and, absent evidence that the parent has sufficiently provided for the child in some other way, refuse to enforce the testator's wishes.

Given the high regard American law has for testamentary freedom, this proposal may initially appear unattainable or perhaps even unwise. However, utilizing parens patriae to curb testamentary freedom in the limited circumstances where disinheritance would amount to child abuse or neglect is instead consistent with the overall approach to American succession law. After all, testamentary freedom is not absolute. Two key limitations are relevant here. First, the law already refuses to enforce testamentary provisions that violate public policy. ${ }^{35}$ Examples include provisions that encourage illegal activity, are premised on racial restrictions, or promote divorce or separation. ${ }^{36}$ To accept this Article's

32. Natalie L. Clark, Parens Patriae and A Modest Proposal for the Twenty-First Century: Legal Philosophy and A New Look at Children's Welfare, 6 MiCH. J. GENDER \& L. 381, 382 (2000).

33. LeWIS HochHeimer, A TREATISE ON THE LAW RELATING TO THE CUSTODY OF INFANTS 1617 (1887); see also Kay P. Kindred, God Bless the Child: Poor Children, Parens Patriae, and a State Obligation to Provide Assistance, 57 OHIO ST. L.J. 519, 521 (1996) ("Despite the weight imparted in both law and social policy to the parent-child relationship and to the values of family privacy, the state, in the proper exercise of its power as parens patriae, can require parents to provide proper food, clothing, shelter and medical care to their children.").

34. Brian H. Bix, Private Ordering and Family Law, 23 J. AM. ACAD. MATRIM. L. 249, 260 (2010).

35. See Daniel B. Kelly, Restricting Testamentary Freedom: Ex Ante Versus Ex Post Justifications, 82 FORDHAM L. REV. 1125, 1162 (2013) (“[A] court may refrain from enforcing a devise on the basis of public policy if the devise entails a significant externality.").

36. Restatement (ThiRd) OF Prop.: Wills AND Other Donative Transfers $\S 10.1 \mathrm{cmt}$. c (AM. LAW INST. 2003) ("Among the rules of law that prohibit or restrict freedom of disposition in certain instances are those relating to spousal rights; creditors' rights; unreasonable restraints on alienation or marriage; provisions promoting separation or divorce; impermissible racial or other 
proposal, then, the law need only recognize parens patriae as a necessary addition to that list - one that is not difficult to defend given the state's strong interest in protecting children. ${ }^{37}$

Second, testamentary freedom is already curtailed by exceptions designed to protect similarly situated classes of individuals, most notably spouses and creditors. ${ }^{38}$ Spouses enjoy nearly universal protection from disinheritance in the various states either through an elective share or community property laws. ${ }^{39}$ The fact that spouses, but not children, are afforded such protection is somewhat ironic given that, unlike spouses, children did not join the family by choice and, at least in the case of minor children, have little ability to protect themselves financially. ${ }^{40}$ Even creditors occupy a better position than children by virtue of the fact that creditors-likely as a result of their greater political influence ${ }^{41}$-are permitted to make claims against a decedent's estate. ${ }^{42}$ As one scholar noted, perhaps children would gain protection from disinheritance if "we thought of them as creditors rather than as loved ones." ${ }^{\text {43 }}$ Regardless of how the law classifies children's interests, the more salient point is that protecting children from disinheritance does not require the law of succession to craft any new frameworks that are not already in place- the law need only recognize the wisdom and necessity of including children within them.

This Article does not, however, go so far as to propose an absolute prohibition on child disinheritance. Although that is the approach taken by a number of countries, such an approach would curtail testamentary freedom too sharply and, as an initial matter, would likely fail to garner

categoric restrictions; provisions encouraging illegal activity; and the rules against perpetuities and accumulations. The foregoing list is illustrative, not exhaustive.").

37. See infra section II.B.

38. See infra notes 324-335 and accompanying text.

39. See Tate, supra note 8 , at 160 (describing how states protect spouses "either through a statutory 'elective share' of the testator's property or by classifying both spouse's earnings as community property, one-half of which belongs automatically to the surviving spouse"); Taite, supra note 31, at 340-41 (explaining how, in a community property system, "[a]t the decedent spouse's death, he can only devise his half of the community property" and thus "[t]he surviving spouse owns her own one half interest of the community estate so there is no need for a minimum share of the decedent's spouse's estate").

40. Brashier, Modern Family, supra note 18, at 182 ("The difference in protection afforded spouses and minor children is particularly ironic when one compares their positions. Spouses have the opportunity and ability to protect themselves from disinheritance; minor children do not.").

41. See Brashier, Protecting the Child, supra note 16, at 22 (noting that minor children "do not have the political power to ensure their protection from disinheritance").

42. See infra notes 333-334 and accompanying text.

43. Haskell, supra note 31, at 508. 
the support needed to become law in the United States. ${ }^{44}$ More importantly, there are compelling justifications that militate in favor of preserving the rights of testators to, in many instances, disinherit their children. ${ }^{45}$ Any proposal that ignored those policies could ultimately harm children even more. As one commentator explains, "[i]f donors believe courts may not facilitate their intent, donors may be less happy, accumulate less property, and alter gifts during life [and, as a result,] may harm not only the donors but also donees as a class. $" 46$

Thus, although this Article puts forth a proposal that would limit the testamentary freedom of a parent to disinherit the testator's children, there are two important limitations. First, the only children who can avail themselves to this exception are those children most in need of the state's protection - a category this Article refers to as "vulnerable child heirs." Included within that subset of children are minor children, disabled adult children whose disabilities are such that they remain dependent upon their parents, and adult children who were abused at the hands of the testator parent during their minority. Second, even when a testator's child falls into one of these three categories, the testator's attempt at disinheritance will still be enforced so long as the disinheritance does not amount to abuse or neglect, meaning that, in the context of dependent children, the parent testator has in some other way sufficiently provided for the child and, in the context of adult survivors of child abuse, the disinheritance is unrelated to the abuse suffered during the child's minority. These limitations, which are discussed in greater detail below, ${ }^{47}$ seek to keep any infringement of testamentary freedom to a minimum while, at the same time, permitting states to fulfill their parens patriae duty to protect those children who cannot protect themselves.

This Article proceeds in four parts. Part I explores the law of child disinheritance, detailing and contrasting the permissive American approach with the more restrictive systems employed by other countries. Part II turns to parens patriae, exploring both the evolution of the doctrine and how it presently operates within the law of domestic relations. Part III details why - in light of the evolving family - the American approach to child disinheritance must change, what it is about the vulnerable child heirs that makes them particularly susceptible to the harms of disinheritance, and why the doctrine of parens patriae provides the most appropriate remedy for protecting them from harm. Finally, Part IV puts

44. See Chester, supra note 20, at 20 ("America's resistance to protecting children via inheritance is rooted in its extreme individualism: the right of disinheritance stems from the protection of individual free will.").

45. See infra notes 100-110 and accompanying text.

46. Kelly, supra note 35 , at 1125.

47. See infra section IV.A. 
forth a proposal for implementing a parens patriae exception to a parent's ability to disinherit their children, focusing on how the proposal would operate vis-á-vis the three categories of vulnerable child heirs and offering responses to some of the potential objections such an approach might engender.

\section{DISINHERITANCE AND THE DEAD HAND}

The dead cannot own property - that much is clear. What is not so clear is the extent to which testators can exert "dead hand control" over the distribution of property that once belonged to them. ${ }^{48}$ At the heart of the question lies the tension between testamentary freedom and the testator's moral duty to support the surviving spouse and children. ${ }^{49}$ Although far from being a zero-sum game, "the allocation of rights to the dead invariably affects the resources available to the living. ${ }^{50}$ In the United States, that debate has largely been settled in favor of the dead hand. As Mark Ascher describes, "[t]he law of wills allows the dead virtually unfettered discretion in divvying up that which used to belong to them, and probate law generally requires the living to effectuate those desires." ${ }^{\prime 1}$

American law has done so out of its commitment to testamentary freedom, frequently referring to it as "[t]he organizing principle of the American law of succession., ${ }^{52}$ Indeed, both legislatures and courts alike are extremely reluctant to take steps that might limit this time-honored freedom - a freedom Melanie Leslie describes as the belief that "[o]ne has a right to distribute property upon death solely according to the dictates of one's own desires, unfettered by the constraints of society's moral code or the claims of others." ${ }^{, 53}$ In many ways, then, testamentary freedom is seen merely as "a logical extension of an owner's freedom to deal with his property during his lifetime" ${ }^{34}$ and thus, "[j]ust as the man who

\footnotetext{
48. See Batts, supra note 1, at 1219 (noting how the "post mortem disposition of the property .... has always been a relative term; the testator has never enjoyed absolute freedom of testation").

49. See Brashier, Modern Family, supra note 18, at 132 (discussing the tension between "balancing testamentary freedom with moral obligation to protect and provide for one's spouse and children").

50. RAY D. MAdOFF, ImMORTALITY AND THE LAW: THE RISING POWER OF THE AMERICAN DEAD 6 (2010); see also Batts, supra note 1, at 1217 ("There also is the two-sided coin aspect of inheritance: the 'heads' side being the right of the decedent to control disposition of the estate, and the 'tails' side being the right of the heir to receive the inheritance.").

51. Mark L. Ascher, But I Thought the Earth Belonged to the Living, 89 TEX. L. REV. 1149, 1149 (2011).

52. Robert H. Sitkoff, Trusts and Estates: Implementing Freedom of Disposition, 58 ST. LOUIS U. L.J. 643, 643 (2014).

53. Melanie B. Leslie, The Myth of Testamentary Freedom, 38 ARIZ. L. REV. 235, 235 (1996).

54. Batts, supra note 1, at 1219 (citations omitted).
} 
produced wealth has the right to use it in his lifetime, so he has the right to choose who shall be its recipient after death." 55

Another rationale for allowing testamentary freedom to play such a central role in the law of inheritance include the belief that it increases donor satisfaction, ${ }^{56}$ thus allowing testators to have peace of mind that "even after death, those whom one cares about can be provided for." Testamentary freedom is also thought to promote not only capital accumulation, ${ }^{58}$ but also "industry and thrift" ${ }^{59}$ given that individuals are likely to work harder and save more if they believe they can direct the distribution of those assets after their death. ${ }^{60} \mathrm{~A}$ third justification comes from the fact that testators, as compared to legislatures and courts, likely "possess better information about the circumstances of family members and other donees," ${ }^{\prime 1}$ thus enabling them to make better decisions regarding how their property should be distributed. Finally, there is the belief that testamentary freedom may actually strengthen families by "provid[ing] parents with greater control over their children and encourag[ing] children to care for their parents." ${ }^{.62}$ As one commentator explained, "the only way to induce children to perform and not to shirk responsibility while waiting for an inheritance is to allow their parents the possibility of disinheriting them. ${ }^{, 63}$ In light of these rationales, American law has come to regard testamentary freedom "not only as a natural almost political right, but a natural condition of all law as well.".64

55. Daniel J. Kornstein, Inheritance: A Constitutional Right?, 36 RUTGERS L. REV. 741, 752 (1984) (citations omitted); see also STEVEN SHAVELL, FOUNDATIONS OF ECONOMIC ANALYSIS OF LAW 65 (2004) ("[B] equeathing property is simply one way of using property.").

56. See Kelly, supra note 35, at 1135.

57. Edward C. Halbach, Jr., An Introduction to Chapters 1-4, in DEATH, TAXES AND FAMILY PROPERTY 3, 5 (Edward C. Halbach, Jr. ed. 1977).

58. See Kelly, supra note 35, at 1136 (“[T] estamentary freedom promotes capital accumulation.”); Tate, supra note 8 , at 158 ("[W]hile people primarily accumulate wealth to guard against future contingencies during life, the desire to bequeath wealth to future generations does play a secondary role.").

59. Halbach, supra note 57, at 4.

60. See, e.g., Adam J. Hirsch \& William K.S. Wang, A Qualitative Theory of the Dead Hand, 68 IND. L.J. 1, 45 (1992) ("Confident that government will fly to the rescue of those in need, citizens of a welfare state may thus be tempted to work fewer hours, to save less of their earnings, and to take greater gambles with their financial resources or careers (human capital) than is socially desirable.").

61. Kelly, supra note 35 , at 1136.

62. Id. at 1137; see also Hirsch \& Wang, supra note 60, at 10 ("The testator's power to bequeath encourages her beneficiaries to provide her with care and comfort-services that add to the total economic "pie."').

63. Pierre Pestieau, Gifts, Wills and Inheritance Law, in 6 ENCYCLOPEDIA OF LAW AND ECONOMICS 96, 109 (Boudewijn Bouckaert \& Gerrit De Geest Eds., 2011).

64. Saul Touster, Testamentary Freedom and Social Control-After-Born Children-Part I: The New York Experience, 6 BUFF. L. REV. 251, 255 (1957). 
Nonetheless, a number of scholars have argued that this characterization of testamentary freedom is, at least in some respects, mere "lip service." 65 There are, after all, a number of instances where the law has forced the dead hand of the testator "to relax its grip." ${ }^{\text {"66 }}$ Indeed, "the dead hand rules succession only by sufferance" 67 and thus legally sanctioned postmortem control is forever at the mercy of the living. Just as there are limits on how property owners may use their property while alive, there are likewise a number of restrictions on how the deceased may direct the use of their former property ${ }^{68}$ Stated generally, testamentary wishes must yield whenever "the donor attempts to make a disposition or achieve a purpose that is prohibited or restricted by an overriding rule of law." 69

Consider, for instance, a Supreme Court's ruling from 1827 that "a testator cannot, by his will, withdraw from his creditors any property which the law subjects to their claims." ${ }^{, 70}$ To this day, the law continues to protect decedents' creditors, ${ }^{71}$ and notably " $[t]$ he cry of invasion of property rights is seldom heard in this connection." "T2 The same could be said of estate tax given that, despite representing "a direct restraint upon donative disposition," ${ }^{73}$ such tax still must be paid. The Uniform Probate Code (UPC) imposes additional restrictions, invalidating testamentary schemes that embody "unreasonable restraints on alienation or marriage; provisions promoting separation or divorce; impermissible racial or other categoric restrictions; [and] provisions encouraging illegal activity." ${ }^{74}$

65. Leslie, supra note 53, at 273.

66. Lawrence M. Friedman, Dead Hands: A Social History of Wills, Trusts, and INHERITANCE LAW 125 (2009).

67. Kelly, supra note 35, at 1166 (citations omitted); see also FRIEDMAN, supra note 66, at 182 ("The brutal fact remains: the dead are definitely dead. The dead 'control' beyond the grave only insofar as living people let them do so.").

68. See Batts, supra note 1, at 1220 ("Society does not hesitate to restrict the uses to which a property owner, while alive, may put his property when it is unreasonably harmful to others, when he has obligations of family support, or when he is indebted to others.").

69. Restatement (ThiRd) OF Prop.: Wills AND Other DONATIVE TRANSFERS $\S 10.1 \mathrm{cmt} . \mathrm{c}$ (AM. LAW INST. 2003).

70. Potter v. Gardner, 25 U.S. 498, 501 (1827).

71. See Kelly, supra note 35, at 1163 (discussing how the Uniform Probate Code safeguards the rights of decedents" creditors); see also infra notes 333-335 and accompanying text.

72. Haskell, supra note 31, at 509.

73. Id. at 510; see also David Horton, Testation and Speech, 101 GEO. L.J. 61, 99 n. 291 (2012) ("For instance, a plaintiff who challenges the federal estate tax or the rule against perpetuities on First Amendment grounds would not be able to prove that either principle calls the genuineness of her testamentary wishes into question. Indeed, these doctrines acknowledge the testator's or settlor's intent but simply refuse to carry it out.").

74. Restatement (ThiRd) OF PROPERTy: Wills AND Other DONATIVE TRANSFERs $\S 10.1 \mathrm{cmt}$. c (AM. LAW INST. 2003). 
When it comes to the family, however, perhaps the biggest limitation on testamentary freedom involves spouses. As Ralph Brashier has noted, "[c]ommitment to testamentary freedom ... has not prevented most state legislatures from enacting substantial statutory protection for disinherited spouses." 75 Indeed, in every state but one, the surviving spouse is the only member of the family who cannot be completely excluded from receiving a portion of the testator's property. ${ }^{76}$ States provide this protection either through an "elective share" (i.e., a percentage of the decedent's estate that the surviving spouse can elect to take in lieu of what - if anything - was provided by the testator ${ }^{77}$ ) or through the protections that flow from community property laws, which automatically classify one-half of the testator's property as belonging to the spouse. ${ }^{78}$ Although there is some debate about just how meaningful these protections are, ${ }^{79}$ they nonetheless exist to try and "ensure that the rare spouse who is disinherited may claim a part of the testator's estate." $" 80$

Testators' children enjoy no such protection. In every state but Louisiana, a "testator is free to disinherit even needy, minor children, regardless of the size of the estate." ${ }^{\prime 1}$ It is hardly surprising, then, that children are the family members most often impacted by disinheritance. ${ }^{82}$ As a number of scholars have noted, the changing American family has only exacerbated this problem, with the result that children today are more likely than ever before to be disinherited ${ }^{83}$ However, before discussing the increasing need for legal protections against disinheritance, it is first necessary to understand how the United States came to adopt its approach to child disinheritance, how those laws currently operate in the United

75. Brashier, Modern Family, supra note 18, at 85.

76. Tate, supra note 8, at 160 ("With the exception of Georgia, every American state limits the ability of a testator to disinherit a surviving spouse.").

77. See Naomi R. Cahn, Parenthood, Genes, and Gametes: The Family Law and Trusts and Estates Perspectives, 32 U. MEM. L. REV. 563, 601 (2002) ("Within trusts and estates law, the freedom to will one's property is subject to a spousal elective share, which entitles a surviving spouse to take property regardless of what a will provides.").

78. See Ray D. Madoff, Unmasking Undue Influence, 81 MinN. L. REV. 571, 612 n.137 (1997) ("The community property system limits the problem of spousal disinheritance since each spouse automatically owns a half-interest in all property acquired during the marriage.").

79. See Foster, supra note 15, at 1218-19 (noting how "[o]mitted spouse and marital property rights provisions award property on the basis of fixed rules and disregard the survivor's actual needs and circumstances") (internal quotation marks omitted).

80. Brashier, Protecting the Child, supra note 16, at 13.

81. Brashier, Modern Family, supra note 18, at 84-85 (emphasis omitted).

82. See Chester, supra note 20 , at 4 ("Accordingly, it is not surprising that those family members aggrieved by disinheritance are overwhelmingly children. In fact, a recent study . . f found that $71.3 \%$ of will contests involved either stepchildren or children, and that only $13.2 \%$ of will contests involved first or second spouses.").

83. See Brashier, Modern Family, supra note 18, at 165 (stating that America's children "now more than ever appear likely to be disinherited"). 
States, and why it is that "[t]he American parent's ability to disinherit his children is unimaginable to most people of the world." ${ }^{84}$

\section{A. The United States Approach}

Throughout the United States-with the notable exception of Louisiana ${ }^{85}$ - " $[\mathrm{t}]$ he intentional disinheritance of a child by a competent testator is both permissible and unchallengeable. ${ }^{" 86}$ In fact, with what has been described as the "American indifference to the disinheritance of children," ${ }^{87}$ a testator is free to go so far as to "pauperize his helpless dependents." ${ }^{\prime \prime 8}$ Like many legal doctrines within the United States, the freedom to disinherit children was imported from England. English law had at one point actually protected children from disinheritance, ${ }^{89}$ but "[b]y the time of the American Revolution, an English testator could indeed exclude his children when bequeathing his chattels." ${ }^{90}$ Although American independence would result in the repudiation of a number of British legal concepts, child disinheritance was not one of them. In fact, the United States would continue to adhere to this approach even after England eventually abandoned it, ${ }^{91}$ resulting in a system today that "defer[s] even more to the Dead Hand than the English."

To illustrate, consider a 1995 Pennsylvania case in which the father died, leaving behind three minor children. ${ }^{93}$ Despite the fact that the father was the custodial parent, he left no part of his estate to his children. ${ }^{94} \mathrm{He}$ instead devised everything to his second wife who, following his death, refused to care for the three children. ${ }^{95}$ The children's mother, who was the testator's first wife, subsequently brought suit, claiming that the decedent's estate was liable for child support. ${ }^{96}$ The lower court dismissed her complaint, and the appellate court affirmed, merely noting - in an

84. RALPH C. BRASHIER, INHERITANCE LAW AND THE EVOlVING FAMILy 91 (2004) [hereinafter BRASHIER, INHERITANCE LAW].

85. See infra notes $147-153$ and accompanying text.

86. Brashier, Modern Family, supra note 18, at 169.

87. Batts, supra note 1, at 1198.

88. Foster, supra note 15, at 1217 (quotations omitted).

89. See Tate, supra note 8 , at $149-54$ (discussing how dissatisfaction with primogeniture lead to a change in the law whereby testators were given greater freedom vis-á-vis their children).

90. Brashier, Protecting the Child, supra note 16, at 17.

91. See infra notes 130-131.

92. Ascher, supra note 51, at 1171.

93. Garney v. Estate of Hain, 653 A.2d 21 (Pa. Super. Ct. 1995).

94. Id. at 22 (Sole, J., dissenting) ("Appellant's three children resided with the deceased and his second wife until the time of death.").

95. Id.

96. Id. 
opinion that spanned less than a single page - that "[t]he decedent disposed of his property as he wished prior to his death and ... absent legislative authority to do so, we decline to rewrite the decedent's will.",97 In support, the court cited an earlier case in which it had held that a "testator with children may disinherit one or all [given that] a testator is free to dispose of property as he sees fit." 98

Considering that one of the primary obligations parents have during life is to support their children, the fact that a parent's death can so easily terminate this obligation-but not others, such as debts owed to creditors - can appear somewhat inconsistent. ${ }^{99}$ To justify this disparity, a number of possible rationales have been put forth. One of the primary justifications for child disinheritance is that it is more efficient if the estate instead passes to the surviving spouse, who in turn will use a portion to benefit the children. ${ }^{100}$ Referred to as a "trickle down" or "conduit effect," 101 the theory is that "the testator's minor children - who are also the children of the surviving spouse-receive indirect protection from disinheritance because of the survivor's continued legal obligation to support those children." 102 As discussed more fully below, however, there is some debate about the extent to which the law can continue to rely on that theory in light of the greater instances of divorce, cohabitation, and remarriage. ${ }^{103}$ Additionally, some argue that protections against disinheritance are unnecessary given that " $[\mathrm{m}]$ ost parents sense their moral obligations to their children and seek to fulfill those obligations to

\section{Id. at 22 .}

98. Id. (quoting In re Agostini's Estate, 457 A.2d 861 (Pa. Super. Ct. 1983)).

99. Paul G. Haskell, Restraints Upon the Disinheritance of Family Members, in DEATH, TAXES AND FAMILY PROPERTY, supra note 57, at 105, 114 ("The moral obligation during life to support one's spouse and minor children was made law, but no comparable legal duty was imposed with respect to transmission of property to children, minor or of age. . ..").

100. See E. Gary Spitko, The Expressive Function of Succession Law and the Merits of Non-Marital Inclusion, 41 ARIZ. L. REV. 1063, 1078 (1999) ("The conduit theory is premised on the notion that a typical decedent with surviving children would view the surviving spouse as both a primary beneficiary-someone who can better manage the property if the surviving children are minors, and is more in need of the property to ensure a secure retirement if the surviving children are adults - and as a conduit-someone who will, in time, pass the property on to the surviving children when the surviving spouse die.").

101. See Brian C. Brennan, Disinheritance of Dependent Children: Why Isn't America Fulfilling Its Moral Obligation?, 14 QUINNIPIAC PROB. L.J. 125, 131 (1999).

102. Brashier, Protecting the Child, supra note 16, at 13-14; see also Judith G. McMullen, Father (or Mother) Knows Best: An Argument Against Including Post-Majority Educational Expenses in Court-Ordered Child Support, 34 IND. L. REV. 343, 355 (2001) ("There is an expectation that the surviving parent will continue to provide for the children, and indeed is legally obligated to do so if the children are minors."); Robert H. Mnookin \& Lewis Kornhauser, Bargaining in the Shadow of the Law: The Case of Divorce, 88 YALE L.J. 950, 995 (1979) (“A decedent cannot, however, disinherit his spouse, and current law effectively entrusts the surviving parent with child-rearing responsibility in the light of existing economic resources.").

103. See infra notes $256-263$ and accompanying text. 
the best of their abilities." ${ }^{\text {"104 }}$ Of course, as Paul Haskell has pointed out, "[t]his is undoubtedly true, but the same can be said for all kinds of aberrational conduct which the law prohibits or punishes." 105

When it comes to disinheriting adult children, other justifications come into play. First, the threat of disinheritance can extract greater caregiving from the testator's children. ${ }^{106}$ Second, the parent may be operating under an "altruistic belief that total disinheritance of one's child forces that child to become a more fully self-actualized individual and contributing member of society." 107 The concern being that children may have less incentive to achieve their full potential if they are guaranteed an inheritance. ${ }^{108}$ As one commentator has noted, however, such arguments may have less force in our modern world where life expectancies have increased so dramatically:

Perhaps in an age when physical danger, rampant disease, frequent wars, plagues, natural disasters, and myriad other lifethreatening and shortening factors severely curtailed adult life expectancies, the fear of children "waiting around" to inherit, rather than getting on with their own lives, may have had some currency. In our present era of miracle drugs, life-saving surgery and technology, health and fitness consciousness, and better diet, all resulting in increased longevity, it is not likely that sixty-yearold "children" are holding their lives in abeyance, waiting for eighty-five and ninety-year-old-parents to finally die and leave them an inheritance. ${ }^{109}$

Somewhat relatedly, a final justification is that a testator may simply regard an aging spouse as more in need of the estate than adult children, who are likely younger and more able-bodied. ${ }^{110}$

104. Brashier, Protecting the Child, supra note 16 , at 7.

105. See Haskell, supra note 99 , at 114.

106. See supra notes 62-63 and accompanying text; see also Tate, supra note 8, at 134 ("Once a punishment inflicted primarily on wayward progeny, disinheritance of adult, non-disabled descendants has become an unfortunate but necessary consequence of the need to reward those who care for their aging parents or grandparents.").

107. Brashier, Protecting the Child, supra note 16, at 7.

108. Asadorian, supra note 22, at 110-11 (noting that a criticism of forced inheritance is that it "might cause heirs to become lazy and unmotivated because they know they will ultimately inherit from their parents."); see also Brennan, supra note 101, at 129 n.20 ("'the very knowledge of the certainty of the inheritance to come' may often deprive children 'of any motive to lead a useful life."') (quoting Alex Shoumatoff, The Mountain Of NAmes 103-05 (1985)).

109. Batts, supra note 1 , at 1221.

110. See Asadorian, supra note 22, at 107 ("In the case of an older testator with adult children, the decedent may feel that the surviving spouse has a greater need for financial support."); see also Brashier, Protecting the Child, supra note 16, at 8 ("With life expectancies and costs of elder care increasing, the testator spouse may feel that most, if not all, of his estate should be devised to the surviving spouse."). 
Despite these justifications for permitting child disinheritance, other areas of American succession law do attempt to protect children from the financial harms that can result from losing a parent. Chief among them are laws regarding intestate succession, which provide default rules for distributing the property of those who die without a will. ${ }^{111}$ In contrast to children whose parents die testate, children whose parents die intestate are virtually guaranteed a portion of their parents' estates. ${ }^{112}$ As Lee-ford Tritt explains, "[t]he most dominant goal of normative defaults is protecting the family." 113 Thus, it comes as little surprise then that "[e]very state intestacy statute provides that, if a decedent leaves 'issue,' the issue will receive a portion of the decedent's estate." ${ }^{114}$ Under California's intestacy law, for instance, children receive half of the estate. ${ }^{115}$

Even in the contexts of wills, there do exist some-albeit modestprotections for children. First, a number of states have enacted pretermitted child statutes, which are designed to protect children from unintentional disinheritance. ${ }^{116}$ They operate by awarding children an intestate share in situations where either the child was born after the execution of the will or the child was born prior to the will but was not specifically referenced in the testamentary document. ${ }^{117}$ But, as Lawrence Friedman has noted, such protections are largely illusory: "The most, then, that can be said is that in some states it takes a slight effort to disinherit a child, but a parent who really wants to leave nothing to his children can do it fairly easily." 118 Finally, there may be limited

111. Robert H. SitKofF \& JesSe DUKEMINIER, Wills, Trusts, AND Estates 63 (10th ed. 2017) ("Distribution of the probate property of [people who die without a will] is governed by the default rules of the law of intestacy." (emphasis in original)).

112. See, e.g., UNIF. ProB. CODE $§ 2$-103(a) (2018) ("Any part of the intestate estate not passing to a decedent's surviving spouse ... or the entire intestate estate if there is no surviving spouse, passes in the following order to the individuals who survive the decedent: (1) to the decedent's descendants by representation.").

113. Lee-ford Tritt, Technical Correction or Tectonic Shift: Competing Default Rule Theories Under the New Uniform Probate Code, 61 ALA. L. REV. 273, 292 (2010).

114. Susan C. Stevenson-Popp, «I Have Loved You in My Dreams»: Posthumous Reproduction and the Need for Change in the Uniform Parentage Act, 52 CATH. U. L. REV. 727, 733 (2003). As used in this context, "issue" refers not only to the decedent's children, but all lineal descendants. See Richard C. Ausness, Planned Parenthood: Adult Adoption and the Right of Adoptees to Inherit, 41 ACTEC L.J. 241, 285 (2015) (“The terms 'descendants,' 'lineal descendants' or 'issue' have the same meaning in legal parlance, namely a person's lineal descendants by blood.”).

115. See CAL. Prob. CODE $\S \S 6401,6401$ (2015).

116. See Lawrence W. Waggoner, The Multiple-Marriage Society and Spousal Rights Under the Revised Uniform Probate Code, 76 IOWA L. REV. 223, 254 (1991).

117. Katherine Shaw Spaht, et al., The New Forced Heirship Legislation: A Regrettable «Revolution», 50 LA. L. REV. 409, 479 (1990) ("About half of the states protect children who are alive when the will was written, not just children born after the will was written, by giving them the share they would have received in intestacy when they have not been mentioned in the will.").

118. FRIEDMAN, supra note 66, at 39. 
protections for minor children whose testator parent was subject to a support decree given that, in some states, such orders survive the death of the parent. ${ }^{119}$ This protection, however, will only serve to benefit a small class of children - those who, during the testator's life, received a court order of support that was still in effect at the time of the testator's death.

Beyond these specific protections, American judges are not above resorting to "covert manipulation of doctrine" 120 in order to effectuate the normative - if not the legal-requirement that testators provide for the surviving members of their nuclear family. ${ }^{121}$ The doctrines in question typically include fraud, undue influence, and testamentary intent ${ }^{122}$ - all of which were originally designed to protect against testamentary devices that do not reflect the testator's free will. ${ }^{123}$ Nonetheless, as other scholars have noted, courts will sometimes stretch the limits of those doctrines in an attempt to effectuate a more "subjectively just distribution of a testator's estate." 124 In one example, a court used undue influence to invalidate the will of a testator who disinherited her two adult sons in favor of the man with whom she had cohabitated for the past four years. ${ }^{125}$ As analyzed by Melanie Leslie in her (aptly-titled) article, The Myth of Testamentary Freedom, the court reached that conclusion despite the fact that "there were few of the traditional indicia of undue influence."126 Instead, the court seemed to focus more on two non-testamentary considerations: (1) "the illicit nature of the [nonmarital] relationship between testator and beneficiary" and (2) the court's apparent view that the disinheritance was unjust in light of the fact that "the sons had gotten

119. Haskell, supra note 31, at 510 ("It is interesting to note that the one instance in which the law has recognized an obligation of the disinheriting parent's estate to support a minor child is one in which there was a support decree in existence prior to the death of the parent; it seems that the minor child was considered to be a creditor of the decedent, and therefore entitled to satisfaction of the decedent's obligation from the decedent's estate.").

120. Leslie, supra note 53, at 236.

121. Ray D. Madoff, supra note 78, at 611 (describing the belief "that unless the family has done something to 'deserve' disinheritance, the bulk of a person's property should be left to his or her spouse and blood relatives").

122. See Ronald Chester, Should American Children Be Protected Against Disinheritance?, 32 REAL Prop. ProB. \& TR. J. 405, 426-27 (1997) ("It is well known that disinherited children in the United States may also resort to the flexible common-law concepts of undue influence, insane delusion, and lack of testamentary capacity to challenge their parents' wills.").

123. See Mark Glover, The Timing of Testation, 107 KY. L.J. 221, 244 (2018) (“[F]raud, duress, and undue influence all involve a wrongdoer undermining the testator's freedom of disposition, so that the estate plan described in a will reflects the wrongdoer's intent rather than the testator's intent.").

124. Leslie, supra note 53, at 289.

125. See Gaines v. Frawley, 739 S.W.2d 950 (Tex. Ct. App. 1987).

126. Leslie, supra note 53, at 250. 
along well with their mother and had been frequent visitors to her home." 127

Although the courts in these cases may be motivated by a desire to protect children from disinheritance, attempting to do so by inflating legal doctrines that were designed to guard against unrelated concerns is hardly an ideal remedy. As one scholar put it, such an approach is "indirect, haphazard, and finally unsatisfactory." 128 Not only were these doctrines never intended to combat "unseemly" testamentary schemes, but judges are inconsistent in even applying them in that manner, thus making it impossible for litigants to rely on any such protection. As a whole, when it comes to child disinheritance, the fact that the current legal protections that do exist in the United States are so few and so limited stand as "a salient indicator of the value America places on testamentary freedom." 129

\section{B. International Approaches}

Although England once permitted testators to freely disinherit their children, ${ }^{130}$ that would all change in the early twentieth century. With the Inheritance (Family Provision) Act of 1938, the "English testator's right to disinherit his children ... for any reason that pleased his fancy" came to an end. ${ }^{131}$ Even though this change occurred more than eighty years ago, it came about primarily because England recognized even then that "very few civilized countries still permitted [the disinheritance of] children." ${ }^{132}$ Nearly forty years earlier, New Zealand had become the first common law country to terminate parents' rights to indiscriminately disinherit their children. ${ }^{133}$ Such protections would eventually spread to other common law countries like Australia, Wales, and several of the Canadian Provinces. ${ }^{134}$ In so doing, these countries joined civil law

127. Id. at 251-52. According to Leslie, "[t] he court briefly wrestled with the question of whether the testator and the beneficiary had had a common-law marriage, noting that 'the formal relationship between testatrix and appellant is relevant to the issue of whether or not the disposition was natural."” Id. at 251 (quoting Gaines, 739 S.W.2d at 951-52).

128. Chester, supra note 20 , at 28.

129. Asadorian, supra note 22, at 106.

130. And that was the approach that existed at the time they established the American colonies. See supra notes 89-92 and accompanying text.

131. Dainow, Limitations on Testamentary Freedom in England, 3 CORNELL L. Q. 337, 337 (1940) ("In July, 1939, there came to an end an epoch of over five centuries' duration.").

132. Brashier, Modern Family, supra note 18, at 122.

133. Terry L. Turnipseed, Why Shouldn't I Be Allowed to Leave My Property to Whomever I Choose at My Death?, 44 BRANDEIS L.J. 737, 753 (2006) ("At the start of the twentieth century, New Zealand became the first common-law jurisdiction to pass legislation providing for certain family members in the case of disinheritance.").

134. See Tate, supra note 8 , at 140. 
countries like France, ${ }^{135}$ where children had long enjoyed protections from disinheritance. ${ }^{136}$ Today, countries throughout the modern world have laws in place to safeguard the inheritance rights of children. ${ }^{137}$

Conspicuously missing from this list is the United States. Thus, to understand the existing methods for protecting children from the harms of disinheritance, one must look to these other countries, which tend to employ one of two approaches: (1) forced share or forced heirship systems, in which children are automatically entitled to inherit a set percentage of the testator's estate; and (2) family maintenance statutes, which permit the testator's family and dependents to petition the court for a discretionary award of some portion of the estate. The remainder of this section offers a brief description of each.

\section{Forced Heirships}

Forced heirships exist in a variety of countries, including the Scandinavian countries, ${ }^{138}$ many of the civil law countries, ${ }^{139}$ and even China. ${ }^{140}$ Under this system, children are entitled to a certain percentage of their parents' estate regardless of "the size of the estate, the age of the children, [or] the need of the children." 141 Those who qualify are referred to as "forced heirs" given that "the testator cannot deprive these heirs from inheriting a portion of the testator's estate - the individuals are 'forced' to be heirs." "142 Thus, in countries that employ this approach, "a person who leaves surviving children never [has] complete freedom of testation, and unless the children merit a just disinherison they always obtain some part of the parent's succession despite contrary disposition by will." ${ }^{143}$ In terms of who qualifies as a forced heir and to what percentage that person is

135. See Taite, supra note 31, at 327 ("Civil law is primarily practiced in continental Europe (specifically Germany, France, and Spain), Russia, China, Japan, Latin America, and parts of Africa."),

136. See Turnipseed, supra note 133, at 753 ("In France, testamentary freedom became taboo after the revolution.").

137. Brashier, Protecting the Child, supra note 16, at 1 ("[P]rovisions protecting children from disinheritance are in place in most modern nations throughout the world.").

138. See Batts, supra note 1, at 1211 (noting that the Scandinavian countries follow the forced heirship model).

139. See Jeffrey Schoenblum, Choice of Law and Succession to Wealth: A Critical Analysis of the Ramifications of the Hague Convention on Succession to Decedents' Estates, 32 VA. J. INT'L L. 83, 119 n.146 (1991) ("Forced heirship is the doctrine followed in many civil law systems.").

140. See Foster, supra note 15, at 1221 ("China has followed the lead of civil law and Scandinavian countries and adopted a forced share approach.").

141. See Batts, supra note 1 , at 1226.

142. Lee-ford Tritt, Liberating Estates Law from the Constraints of Copyright, 38 RUTGERS L.J. 109, 113 n.10 (2006).

143. Dainow, supra note 131 , at 337. 
entitled, countries take different approaches. ${ }^{144}$ In Brazil, for instance, spouses as well as children are considered forced heirs and possess "an indivisible right to at least 50 percent of the deceased's estate." 145 In the Netherlands, however, only children qualify as forced heirs and each child is entitled to half of what he or she would have inherited had the parent died intestate. ${ }^{146}$

The forced heirship model is not a complete stranger to the United States. Louisiana, as the lone state to protect the inheritance rights of children, does so by drawing upon its civil law traditions and employing a forced heirship approach, called the legitime. ${ }^{147}$ Even Louisiana, however, is not immune to the American desire to maximize testamentary freedom. As a result, Louisiana's protections are much more modest than most of the countries that have implemented a forced heirship approach. ${ }^{148}$ In 1921, Louisiana had made forced heirships part of the state constitution, providing that "[n]o law shall be passed abolishing forced heirship." "149 Eventually, however, Louisiana would amend its constitution to limit the class of forced heirs to only those children who are "twentythree years of age or younger ... [or] who, because of mental incapacity or physical infirmity, are incapable of taking care of their persons or administering their estates." 150 Even children who fall into these categories, however, can be disinherited for "just cause," situations where the child has physically harmed the parent or falsely accused the parent of a serious crime. ${ }^{152}$ For the remaining children who

144. Ryan McLearen, International Forced Heirship: Concerns and Issues with European Forced Heirship Claims, 3 EST. PlAN. \& CMTY. PROP. L.J. 323, 341 (2011) ("Even though most civil law jurisdictions originated from the Napoleonic Code, today, European countries have an array of forced heir distribution structures as a result of years of cultural evolution.").

145. Elisabeth Libertuci, Brazil, in U.S. InTERNATIONAL EstATE PlANNING *2 (2019), Westlaw USIEP WGL 96.04.

146. Aaron Schwabach, Of Charities and Clawbacks: The European Union Proposal on Successions and Wills as a Threat to Charitable Giving, 17 COLUM. J. EUR. L. 447, 461 (2011).

147. Tate, supra note 8, at 139 ("Although the testator has the freedom to bequeath a substantial part of the estate to persons of the testator's choosing, the statute reserves a certain portion, called the legitime, for qualified children and other lineal descendants entitled to take by representation.").

148. See Taite, supra note 31, at 335 ("Among the forced share jurisdictions, Louisiana is a moderate version.").

149. LA. CONST. of 1921 , art. IV, $\S 16$.

150. LA. CONST. art. $12, \S 5$.

151. LA. CIV. CODE ANN. art. 1494 (2018).

152. The full list contains eight different examples of "just cause":

(1) The child has raised his hand to strike a parent, or has actually struck a parent [ ]; (2) The child has been guilty, towards a parent, of cruel treatment, crime, or grievous injury; (3) The child has attempted to take the life of a parent; (4) The child, without reasonable basis, has accused a parent of committing a crime for which the law provides that the punishment could be life imprisonment or death; (5) The child has used any act of violence or coercion to hinder a parent from making a testament; (6) The child, being a minor, has married without the consent of the parent; (7) The child 
can avail themselves to the legitime, they are entitled to one-half of the testator's estate; one-fourth if there is only one forced heir. ${ }^{153}$

Thus, to varying degrees, forced heirship jurisdictions offer children protection from disinheritance. An additional benefit of this approach is the certainty that comes from knowing, for any given testator, which family members can avail themselves of these protections and to what percentage they are entitled. With that certainty comes "procedural simplicity," 154 thus preventing judges from substituting their own discretion when determining exactly how to distribute a testator's estate. At the same time, one of the problems with the forced heirship approach is that it is not particularly responsive to the needs of those children who seek its benefits. ${ }^{155}$ Thus, if a testator leaves behind more than one forced heir, both will take equal amounts regardless of their individual circumstances. ${ }^{156}$ Further, the amount the forced heir(s) can claim is limited to a certain percentage of the estate, which may or may not be sufficient to cover the child's needs. ${ }^{157}$ Finally, because the forced heirship model infringes upon the testator's freedom to disinherit children, it raises many of the concerns, noted earlier, ${ }^{158}$ that the American approach seeks to prevent - chief among them the concern that "guaranteed inheritance... might cause heirs to become lazy and unmotivated because they know they will ultimately inherit from their parents." 159

\section{Family Maintenance Statutes}

Whereas civil law countries protect children from disinheritance using forced heirships, common law countries like England, Australia, and

has been convicted of a crime for which the law provides that the punishment could be life imprisonment or death; and (8) The child, after attaining the age of majority and knowing how to contact the parent, has failed to communicate with the parent without just cause for a period of two years, unless the child was on active duty in any of the military forces of the United States at the time.

LA. CIV. CODE ANN. art. 1621(A) (2018).

153. See LA. Civ. CodE ANN. art. 1495 (2018).

154. Asadorian, supra note 22, at 110.

155. See Batts, supra note 1, at 1226 (noting that, under the forced heirship model, "[n]either the size of the estate, the age of the children, nor the need of the children is relevant").

156. See Foster, supra note 15, at 1213 ("Forced heirship's scheme of arbitrary, 'fickle fractions' does not recognize let alone address differing individual needs among the decedent's surviving dependents.").

157. See Haskell, supra note 31, at 518 ("[F]orced heirship goes a long way in the protection of the children and parents of the decedent. It does, however, have the disadvantage of not relating to the need of the surviving dependent.").

158. See supra notes 101-110 and accompanying text.

159. Asadorian, supra note 31 , at $110-11$. 
Canada $^{160}$ rely upon family maintenance statutes, which authorize "a discretionary judicial process that can provide for the needs of a surviving child by overriding a parent's will upon a showing of just cause." ${ }^{.161}$ In other words, these statutes allow certain parties - typically the testator's immediate family and dependents - to petition for an award greater than what the testator directed. ${ }^{162}$ Thus, the family maintenance approach, in contrast to forced heirships, offers courts much more flexibility, "effectively permit[ing] a judge not only to alter the testamentary wishes of the decedent, but also to do so in a highly discretionary manner."163

The courts' discretion, however, is not unlimited. The chief limitation entails the small class of people who have standing to petition the court for relief. Consider, for instance, the family maintenance statute from British Columbia:

Notwithstanding any law or statute to the contrary, if a testator dies leaving a will which does not, in the court's opinion, make adequate provision for the proper maintenance and support of the testator's wife, husband or children, the court may, in its discretion, in an action by or on behalf of the wife, husband or children, order that the provision that it thinks adequate, just and equitable in the circumstances be made out of the estate of the testator for the wife, husband or children. ${ }^{164}$

Beyond limiting those who have standing to petition for maintenance, most statutes also enumerate factors intended to guide courts as they adjudicate whether a disinherited child is entitled to relief. ${ }^{165}$ As Ray Madoff explains, the English law regarding family maintenance directs the courts to take into account a number of considerations including the "resources and needs that the applicant currently has and is likely to have in the foreseeable future; the size and nature of the decedent's estate; any

160. See Jeffrey E. Stake, Biologically Biased Beneficence, 48 ARIZ. ST. L.J. 1101, 1116 (2016) (noting that "England, Australia, New Zealand, and some Canadian provinces" use family maintenance statutes).

161. Brennan, supra note 101 , at 125-26.

162. See Leslie, supra note 53, at 237 ("Those statutes give courts extraordinarily broad discretion to ignore the provisions of a will and distribute testators' estates to family or dependents on the ground that the testator has a moral obligation to provide for them."); FRIEDMAN, supra note 66, at 43 (noting how England's family maintenance statute gives judges the discretion "to allot money from an estate to wives and husbands, former wives or husbands who are single, children, and anybody else the deceased was supporting.").

163. Brashier, Modern Family, supra note 18, at 124-25.

164. Wills Variation Act, R.S.B.C., c.435, § 2(1) (1979) (Can.) [https://perma.cc/988H-M3WH] (emphasis added).

165. See Jennifer R. Boone Hargis, Solving Injustice in Inheritance Laws Through Judicial Discretion: Common Sense Solutions from Common Law Tradition, 2 WASH. U. GLOB. STUD. L. REV. 447,458 (2003) (noting that, although the laws "differ significantly," all contain at least some factors to guide the court). 
physical or mental disabilities of the applicant; and ... the conduct of the applicant." 166

Those scholars who advocate for the family maintenance approach do so on the basis that it not only protects children, but also preserves some degree of testamentary freedom. ${ }^{167}$ Unlike forced heirs who will almost certainly inherit a certain percentage of the parent's estate, ${ }^{168}$ the family maintenance approach provides at least the possibility that the court could uphold the testator's wishes. To the extent the family maintenance approach is at odds with testamentary freedom, supporters do acknowledge that fact but nonetheless characterize that interference as minimal and, in any event, justified by its ability to protect needy or deserving family members. ${ }^{169}$

Nonetheless, the chief criticism of the family maintenance scheme is that it is imbued with uncertainty in several respects. ${ }^{170}$ First, from the testator's perspective, the existence of family maintenance provisions makes it difficult to know exactly how the estate will be divided given that the testator's wishes can be overridden. ${ }^{171}$ Second, in contrast to forced heirs, those who petition for an inheritance pursuant to a family maintenance statute do so without much certainty as to what, if anything, they are entitled. As Brashier describes, family maintenance statutes lack "well-defined guidelines to lend some element of certainty and predictability to the outcome of a claimant's application against the

166. Ray D. Madoff, Lurking in the Shadow: The Unseen Hand of Doctrine in Dispute Resolution, 76 S. CAL. L. REV. 161, 183-84 (2002). In contrast, in New Zealand "the only factor listed in the statute that courts may take into account is the decedent's intent, and the conduct of the applicant [which] may disqualify him from receiving part of the estate." Hargis, supra note 165, at 458 n.69.

167. See Asadorian, supra note 22, at 112 ("The flexibility inherent in the family maintenance system speaks to the natural desire to protect children in need while allowing for some degree of testamentary freedom.").

168. See supra section I.B.1.

169. See Asadorian, supra note 22, at 112 ("[P]roponents of the family maintenance model praise its protection of family members, particularly children, with the least possible interference with testamentary freedom.”).

170. Mary A. Glendon, Fixed Rules and Discretion in Contemporary Family Law and Succession Law, 60 TUL. L. REV. 1165, 1188 (1986) ("English family provision legislation has ceased to be merely a way to provide maintenance for needy spouses and dependent children. It now serves as a charter that allows judges to devise a substantially new estate plan for the deceased in a courtroom setting with a potentially large and colorful cast of characters as petitioners."); see also Susan N. Gary, Marital Partnership Theory and the Elective Share: Federal Estate Tax Law Provides a Solution, 49 U. MIAMI L. REV. 567, 581 (1995) (discussing how such an approach would "introduce a high degree of uncertainty into estate planning, an area in which consistency and predictability are important").

171. Brashier, Modern Family, supra note 18, at 132 ("Although the English courts have stated that theirs is not the prerogative to ignore or refashion the testator's will in general, the testator can seldom if ever be certain that his last will and testament will be honored upon his death."). 
testator's estate." 172 The standards are so "nebulous"173 that some have hypothesized that if the testator disinherited two different children who were similarly situated in all respects, each could still obtain different awards simply by filing their claims in different courts. ${ }^{174}$ Finally, critics note that the practical effect of these statutes is to recast the judge in the role of "surrogate testator," 175 which is problematic given that the judge must make such determinations "without any personal experience of the relevant facts" $" 176$ and, of course, after the testator is no longer around to testify.

Despite their limitations, the forced heirship system and the family maintenance statutes remain the two prevalent approaches for addressing the harms of child disinheritance. However, when it comes to the American law of succession, which places greater emphasis on testamentary freedom, ${ }^{177}$ each approach likely goes too far in curtailing that freedom. Both models would severely limit parents' ability to disinherit their child, as forced heirships would prohibit such actions outright and family maintenance statutes would make it highly uncertain whether such actions would ever be given effect. Thus, it is the position of this Article that another approach is needed — one that limits the court's discretion to override testamentary intent and yet, at the same time, safeguards the interests of those children most in need of protection. As detailed in the remainder of this Article, the doctrine of parens patriae provides a particularly appropriate means for achieving that balance.

\section{PARENS PATRIAE}

Often thought of as merely the state's right to intervene in family affairs for purposes of protecting children, parens patriae is more broadly understood as both the right and the duty ${ }^{178}$ of the state "to make decisions

172. Id. at 125 (footnote omitted).

173. BRASHIER, INHERITANCE LAW, supra note 84, at 109.

174. Id. at 108 ("Under the system, courts address the question of disinheritance on a case-by-case basis and may provide substantially different awards from one case to the next."); see also Andrew Watson Brown, China and the United States: Yin and Yank Intestacy, 59 SANTA CLARA L. REV. 239, 254 (2019) ("Critics contend that the family maintenance model introduces unnecessary complexity and inconsistency into the probate system, thereby promoting litigation, increasing costs and depleting estates.").

175. Tate, supra note 8 , at 141 ; see also Taite, supra note 31 , at 338 (describing the New Zealand family maintenance statute as one that "abdicates a lot of power to the judicial system").

176. Tate, supra note 8 , at 142 .

177. See supra section I.A; BRASHIER, INHERITANCE LAW, supra note 84, at 109 ("Americans appear to love their testamentary freedom more than do citizens in most countries . ...").

178. Mary Koll, Growth, Interrupted: Nontherapeutic Growth Attenuation, Parental Medical Decision Making, and the Profoundly Developmentally Disabled Child's Right to Bodily Integrity, 2010 U. ILL. L. REV. 225, 244 (2010) ("Parens patriae confers on the state a 'right, indeed, a duty, to 
that are in the best interests of vulnerable persons." ${ }^{179}$ The doctrine has a long and somewhat checkered history, having existed over the years in various incarnations and having been employed in a number of different contexts. ${ }^{180}$ Through it all, however, parens patriae has "exhibited a remarkable staying power," ${ }^{181}$ and today enjoys a permanent place in American law. ${ }^{182}$ The purpose of this Part is to look more closely at this doctrine with an aim of better understanding the role it should ultimately play in the law of parental disinheritance. Before getting to what that role might look like, it is necessary to understand, first, the historical evolution of the doctrine and, second, how the doctrine currently operates within the realm of domestic relations.

\section{A. A Brief History}

The concept of parens patriae dates back to the seventeenth century with an origin story that has been described as "probably without parallel in the history of Anglo-American legal institutions." 183 That characterization comes from the fact that what is today an expansive legal doctrine owes its existence to a simple printing error. Parens patriae originally emerged as an extension of the Prerogative Regis, ${ }^{184}$ which "held that the King was personally sovereign and that he was to have preeminence over all within his kingdom. $" 185$ In its earliest form, parens

protect children' by intervening 'in family matters to safeguard the child's health."') (quoting In re Phillip B., 156 Cal. Rptr. 48, 51 (Cal. Ct. App. 1979)).

179. Id.; see also Jasmine E. Harris, Processing Disability, 64 AM. U. L. Rev. 457, 459 (2015) (describing the "parens patriae tradition of the state as 'protector' of vulnerable populations").

180. George B. Curtis, The Checkered Career of Parens Patriae: The State as Parent or Tyrant?, 25 DEPAUL L. REV. 895, 895 (1976) ("The term parens patriae has enjoyed or, better, endured a varied history of both usage and interpretation.").

181. Id.

182. Id. (noting how "American courts have accepted this aspect of the sovereign prerogative and incorporated it into their decisional jurisprudence" and expanded upon it); see also Kevin A. Robinson, Has the Government Failed to Protect Us? A Discussion of HFCS \& Other Added Sugars, 14 J. HEALTH \& BiOMEDICAL L. 365, 368 n.20 (2018) ("[S]tates often invoke parens patriae to protect the health and welfare of its people."); Gregory A. Loken, Gratitude and the Map of Moral Duties Toward Children, 31 ARIZ. ST. L.J. 1121, 1122-23 (1999) ("Anglo/American law has always treated biological parents as responsible for their children's welfare, and for at least the past century has recognized the parens patriae responsibility of the state toward children whose welfare is threatened.").

183. Lawrence B. Custer, The Origins of the Doctrine of Parens Patriae, 27 EMORY L.J. 195, 195 (1978).

184. Amelia C. Waller, State Standing in Police-Misconduct Cases: Expanding the Boundaries of Parens patriae, 16 GA. L. REV. 865, 873 n.50 (1982) ("Although the actual origins of the term parens patriae remain unclear, there is general agreement that it originated in the Prerogative Regis.").

185. Kenneth J. Figueroa, Immigrants and the Civil Rights Regime: Parens Patriae Standing, Foreign Governments and Protection from Private Discrimination, 102 CoLUM. L. REV. 408, 431 n.119 (2002). See also Curtis, supra note 180, at 896 ("Under this theory, the king could do no wrong; he could never die; he was the representative of the state in its dealings with foreign nations; he was 
patriae only encompassed the Crown's ability to protect "lunatics (the temporarily insane) and idiots (the permanently insane)." "186 That all changed, however, in the 1722 case of Eyre v. Countess of Shaftsbury. ${ }^{187}$ There, the court acknowledged the traditional understanding that parens patriae existed for the benefit of "idiots and lunatics, who are uncapable to take care of themselves" but then broadened the doctrine even further, adding that the traditional reasoning also justified "extend[ing] this care to infants." ${ }^{188}$ In extending the doctrine to cover children, the court found support in Beverley's Case, ${ }^{189}$ an opinion issued more than a hundred years earlier, which stated "[t]hat if an infant who cannot defend, govern, or order his lands, tenements, goods, or chattels, the King of right ought to have him in his custody, and to protect him.," ${ }^{190}$ Unbeknownst to the court, however, the publishers of Coke's Reports, wherein the court had located the earlier case, had made a mistake. ${ }^{191}$ Specifically, when reproducing the text of Beverly's Case, the book's printer accidentally substituted the word "infant" for "idiot"- the word the issuing court had actually used. ${ }^{192}$ It would take over a hundred years before the error was corrected, ${ }^{193}$ but by then parens patriae was widely understood to permit state intervention on behalf of children although the exact reach of that doctrine would continue to evolve. ${ }^{194}$

It was this basic understanding, however, that operated in the early laws of American colonies, each of which "imported the equitable powers of parens patriae to protect individuals who lacked the capacity to protect themselves." ${ }^{195}$ Of course at that time only the Crown could exercise that

part of the legislature, the head of the army, the fountain of justice, always present in all his courts, the fountain of honor, the arbiter of commerce, the head of the church.").

186. Jack Ratliff, Parens Patriae: An Overview, 74 TUL. L. REV. 1847, 1850 (2000).

187. 24 Eng. Rep. 659 (c. 1722).

188. Custer, supra note 183, at 202-03 (quoting id. at 664). In this context, "infants" refers to children who have not yet reached the age of majority. See Robert L. Stenger, Exclusive or Concurrent Competence to Make Medical Decisions for Adolescents in the United States and United Kingdom, 14 J. L. \& HEALTH 209, 210 (2000) ("Those who have not reached the age of majority or adulthood, which at common law was twenty one and now generally is eighteen, were called 'infants', [sic] later 'children' or 'minors."').

189. 76 Eng. Rep. 1118 (K.B. 1603).

190. See Custer, supra note 183, at 203 (emphasis added).

191. See 4 Coke's Rep. 126b (London 1658).

192. See Custer, supra note 183 , at 203 (quoting $i d$. at 1658).

193. Id. at 204 ("Not until the 1826 edition was the error corrected so that the word 'idiot' appeared throughout the Beverley's Case opinion.").

194. Ratliff, supra note 186, at 1850 (noting that, by the time the error was corrected, "the Eyre holding ... was well entrenched as precedent").

195. Michael L. Rustad \& Thomas H. Koenig, Reforming Public Interest Tort Law to Redress Public Health Epidemics, 14 J. HeAlth CARE L. \& POL'Y 331, 339 (2011). 
authority. ${ }^{196}$ Given the connection between the doctrine and the monarchy, one might think that parens patriae would have ceased to exist once the colonies moved to a republican form of government. The doctrine, however, not only survived but soon found a home in the various state legislatures, "which often delegated the authority to protect minors and incompetents to the courts." 197 In 1839, the Pennsylvania Supreme Court, in Ex Parte Crouse, ${ }^{198}$ would become the first court in America to employ the term in a written opinion. ${ }^{199}$ In deciding whether the state could commit a child exhibiting "vicious conduct" 200 to a juvenile detention facility without a trial by jury, the court began its opinion by posing a series of rhetorical questions:

[M]ay not the natural parents, when unequal to the task of education, or unworthy of it, be superseded by the parens patriae, or common guardian of the community? It is to be remembered that the public has a paramount interest in the virtue and knowledge of its members, and that of strict right, the business of education belongs to it. That parents are ordinarily intrusted with it is because it can seldom be put into better hands; but where they are incompetent or corrupt, what is there to prevent the public from withdrawing their faculties, held, as they obviously are, at its sufferance? 201

Finding that the state's power in this regard "cannot be doubted," the court upheld the state's right to detain the child. ${ }^{202}$ By 1890, the U.S. Supreme Court would declare that parens patriae was "inherent in the

196. Curtis, supra note 180, at 897 ("Initially, parens patriae established the king as a protector or supreme guardian of those classes threatened by forces beyond their control."); see also Neil Howard Cogan, Juvenile Law, Before and After the Entrance of Parens Patriae, 22 S.C. L. REV. 147, 161 (1970) ("[W]e can conclude that in the seventeenth century the king's relation to idiots and lunatics was that of guardian to ward, that the guardianship was a duty of care rather than a source of profit.").

197. Civil Commitment of the Mentally Ill, 87 HARV. L. REV. 1190, 1208 (1974); see also Allan Kanner, The Public Trust Doctrine, Parens Patriae, and the Attorney General as the Guardian of the State's Natural Resources, 16 DUKE ENVTL. L. \& POL'Y F. 57, 68 (2005) (“After the American Revolution, the rights of the sovereign passed to the governments of the individual colonies."); Late Corp. of the Church of Jesus Christ of Latter-Day Saints v. United States, 136 U.S. 1, 57 (1890) ("This prerogative of parens patriae is inherent in the supreme power of every state, whether that power is lodged in a royal person, or in the legislature.").

198. 4 Whart. 9 (Pa. 1839).

199. See Francine T. Sherman, Justice for Girls: Are We Making Progress?, 59 UCLA L. REV. 1584,1589 (2012) (describing the case as "the first articulation of the principle of parens patriae").

200. 4 Whart. 9, 10 (Pa. 1839).

201. Id. at 11 .

202. Id. 
supreme power of every state ... for the prevention of injury to those who cannot protect themselves." ${ }^{203}$

As the Pennsylvania Supreme Court's decision in Ex Parte Crouse makes clear, the reach of the parens patriae doctrine was growing. In England, the term had merely applied to the monarch's ability to protect dependent children; but legal reformers in the nineteenth century would expand the doctrine to likewise empower the state to control delinquent children. ${ }^{204}$ Indeed, the doctrine has repeatedly proven itself to be quite adaptive - or as one commentator called it, "an absorptive doctrine" 205 and over time would be increasingly invoked to justify even greater governmental interventions. For instance, today the doctrine exists in a number of different contexts, "from protection of the mentally ill to the law of juvenile courts." ${ }^{206}$ Additionally, parens patriae now protects more than just specific individuals who cannot care for themselves, but also encompasses public health, finding application in "environmental mass torts such as global warming, lead paint, handguns, tobacco, public hospitals, predatory lenders, environmental pollution, and climate change." 207

Despite its expansion, parens patriae continues to play an active, crucial role in the law of domestic relations. As John Kleinig explains, "parents sometimes fall unacceptably short of the moral minima that limit their paternalistic role... [a]nd so the state also exercises a parens patriae function ... compel[ing] parents to act in certain ways toward their children." ${ }^{208}$ The following section delves more deeply into the role that parens patriae plays in the realm of family law, looking at the history behind that interplay and the current understanding and application of the doctrine.

203. Late Corp. of the Church of Jesus Christ of Latter-Day Saints v. United States, 136 U.S. 1, 57 (1890).

204. As George Curtis has noted, originally in England, "[t]he motivating reason to apply the parens patriae theory was the need to support and to care for children ... who stood as a source of hope for the kingdom." Curtis, supra note 180, at 899. Individuals who favored juvenile reform, however, "saw its application to the delinquent as "merely a logical extension of the principle of chancery and of guardianship." Id. (quoting H. LOU, JUVENILE COURTS IN THE UNITED STATES 5 (1929)).

205. Id. at 915. See also Claudine Columbres, Targeting Retail Discrimination with Parens Patriae, 36 COLUM. J. L. \& SoC. PROBS. 209, 211 (2003) (describing parens patriae as an "enigmatic doctrine" that is sufficiently flexible "to adjust to modern circumstances").

206. Sarah Abramowicz, English Child Custody Law, 1660-1839: The Origins of Judicial Intervention in Paternal Custody, 99 CoLUM. L. REV. 1344, 1346-47 (1999).

207. Michael L. Rustad \& Thomas H. Koenig, Parens Patriae Litigation to Redress Societal Damages from the BP Oil Spill: The Latest Stage in the Evolution of Crimtorts, 29 UCLA J. ENVTL. L. \& POL'Y 45, 81-83 (2011) (internal citations omitted).

208. JoHn KLEINIG, PATERNALISM 143-44 (1983). 


\section{B. Usage in Contemporary Family Law}

Within the law of domestic relations, parens patriae is understood to stand for the proposition that a parent's right to direct the upbringing of a child is not absolute but must instead yield to the state's interest in protecting the child from abuse and neglect. ${ }^{209}$ Stated differently, "[t]he state can override parental decision-making, but only when the parents are seriously violating their duties toward their children, when the health or well-being of a child is at risk." ${ }^{210}$ But the state's ability to intervene in an existing family is only one aspect of the parens patriae doctrine. The state has enormous legal power to act on behalf of its children. As Jeffrey Shulman explains, "[a]s parens patriae, the state has plenary power to legislate on behalf of the child. The interest of the state in its children is so broad 'as to almost defy limitations.", 211

It was pursuant to that power that state legislatures in the nineteenth century began expanding parens patriae to justify legal intervention not only for the benefit of those children who lacked parents or guardians, but also for those children being abused or neglected. ${ }^{212}$ Accordingly, "[t]he state as parens patriae, as an institution standing in loco parentis, had the right, indeed the duty, to take children out of homes where they were beaten or tortured; or in which they were starved or neglected." ${ }^{213}$ In other words, parens patriae came to stand for the proposition that the state could enforce "a certain modicum of care in the upbringing of children." ${ }^{214}$ This expansion brought with it the idea that children were individuals in their own right subject to the law's protection and not merely the property of their parents ${ }^{215}$ : "Traditionally, children's rights were limited; however,

209. See Kay P. Kindred, supra note 33, at 521 ("Despite the weight imparted in both law and social policy to the parent-child relationship and to the values of family privacy, the state, in the proper exercise of its power as parens patriae, can require parents to prove proper food, clothing, shelter and medical care to their children.").

210. JOANNA L. GROSSMAN \& LAWRENCE FRIEDMAN, INSIDE THE CASTLE: LAW AND THE FAMILY IN 20TH CENTURY AMERICA 262 (2011).

211. JeFFrey SHULMAN, The CONSTITUTIONAL PARENT 56 (2014) (quoting In re Lippincott, 124 A. 532, 533 (N.J. Ch. 1944)).

212. See Vivian Hamilton, Principles of U.S. Family Law, 75 ForDHAM L. REV. 31, 64 (2006) ("In the nineteenth century, state legislatures began enacting child abuse and neglect laws that authorized governmental intervention into abusive parent-child relationships.").

213. GROSSMAN \& FRIEDMAN, supra note 210, at 18; see also supra note 178.

214. Neal Devins, Gender Justice and Its Critics, 76 CALIF. L. REV. 1377, 1402 (1988).

215. In the early nineteenth century, "children were treated essentially as property owned exclusively by the husband and father or, if illegitimate, by the mother." Thomas L. Fowler \& Ilene B. Nelson, Navigating Custody Waters Without A Polar Star: Third-Party Custody Proceedings After Petersen v. Rogers and Price v. Howard, 76 N.C. L. REV. 2145, 2154 (1998). Eventually, however, "in the late nineteenth century and early twentieth century . . public awareness, concern, and outrage over the treatment of children grew. The courts gradually acknowledged that states had parens patriae authority to protect children from abuse and cruelty and upheld criminal child abuse statutes." Id. 
the state grew more receptive to the concerns of children as it realized that children were not able to protect themselves from societal ills or parental abuse." ${ }^{216}$ In the twentieth century, states would expand these laws even further to protect children not only from physical harm, but emotional harm as well. ${ }^{217}$ Under the doctrine of parens patriae, the states felt they had both a right and a duty to intervene. ${ }^{218}$

To the extent there was any question regarding the states' ability to interfere with parental decision-making, the answer came in 1944 with the Supreme Court's decision in Prince v. Massachusetts. ${ }^{219}$ There, Sarah Prince was the aunt and legal guardian of nine-year-old Betty, whom Sarah permitted to sell religious-themed magazines on a public street. ${ }^{220}$ As a result, Sarah was convicted of violating the state's child labor laws, and she appealed. ${ }^{221}$ In previous decisions, the Court had recognized the fundamental rights of parents (and legal guardians) to direct the upbringing of children. ${ }^{222}$ Relying on those precedents, Sarah claimed that her conviction infringed upon her "parental right as secured by the due process clause" of the Fourteenth Amendment. ${ }^{223}$ The Court, however, rejected her claim, stating as an initial matter that "the family itself is not beyond regulation in the public interest." ${ }^{224}$ The Court then held that "[a]cting to guard the general interest in youth's well being, the state as parens patriae may restrict the parent's control by requiring school attendance, regulating or prohibiting the child's labor and in many other ways." 225 Finding that "[p]arents may be free to become martyrs themselves ... [but not] make martyrs of their children" before they reach

216. Christopher R. Pudelski, The Constitutional Fate of Mandatory Reporting Statutes and the Clergy-Communicant Privilege in a Post-Smith World, 98 Nw. U. L. REV. 703, 733 (2004). Despite these developments, it would take some time before the courts would truly recognize children's rights independent of their parents. See Margaret F. Brinig, The Effect of Transaction Costs on the Market for Babies, 18 SeTON HALl LEGIS. J. 553, 562 (1994) ("Despite the possibility that the state might act in parens patriae, the idea that children might have independent rights took another hundred years to develop.").

217. In re Dep't of Pub. Welfare, 421 N.E.2d 28, 36 (Mass. 1981) (observing that "[t]he State as parens patriae may act to protect minor children from serious physical or emotional harm").

218. See Daniel L. Hatcher, Purpose v. Power: Parens Patriae and Agency Self-Interest, 42 N.M. L. REV. 159, 164 (2012) ("As the doctrine began to appear in American jurisprudence, it provided not merely authority but a duty to the vulnerable - with a humanitarian and benign aim.").

219. 321 U.S. 158 (1944).

220. Id. at $159-60$.

221. Id. at 159 .

222. Id. at 166 (citing Meyer v. Nebraska, 262 U.S. 390 (1923) and Pierce v. Soc'y of Sisters, 268 U.S. 510 (1925)).

223. Id. at 164 (noting that "she rests squarely on freedom of religion under the First Amendment," using the Fourteenth Amendment to apply the First Amendment to the states).

224. Id. at 166 ("And neither rights of religion nor rights of parenthood are beyond limitation.").

225. Id. (emphasis added). 
the age of majority, the Court upheld Prince's conviction. ${ }^{226}$ In the following decades, the Supreme Court would regularly affirm this understanding of the states' rights vis-à-vis parents. ${ }^{227}$

In so ruling, the Supreme Court made clear that the overriding purpose of parens patriae is to protect society as a whole. Indeed, when describing the Court's holding in Prince, one commentator observed that "although the Supreme Court recognizes the profound role parents play in shaping their children's behaviors, it allows for state intervention not necessarily to protect youths' rights but to protect the rights of society." 228 In fact, the Court itself would later characterize parens patriae as "a most beneficent function often necessary to be exercised in the interest of humanity." 229 This connection between children and society stems from the reality that the strength of humanity's future is heavily dependent on the health and well-being of today's children. ${ }^{230}$ Thus, parens patriae operates under the hope that "the child would save the state as well as the state the child.",231

Today, state courts enjoy broad, inherent powers to protect childrenpowers that go well beyond simply removing children from environments deemed abusive or neglectful. ${ }^{232}$ Courts are free to exercise these powers "whenever necessary" and through "whatever relief may be necessary to protect [the children's] best interests." ${ }^{233}$ Further, this duty arises even in the absence of any direction from the state legislature. After all, "each branch of government has concurrent powers and responsibilities that are

\section{Id. at 170 .}

227. See, e.g., Troxel v. Granville, 530 U.S. 57, 88 (2000) (Stevens, J., dissenting) (pointing out the "Court's assumption that a parent's interests in a child must be balanced against the State's longrecognized interests as parens patriae"); Bowen v. Am. Hosp. Ass'n, 476 U.S. 610, 627 (1986) ("[S]tate law vests decisional responsibility in the parents, in the first instance, subject to review in exceptional cases by the State acting as parens patriae."); Schall v. Martin, 467 U.S. 253, 265 (1984) (noting that "[c]hildren ... are assumed to be subject to the control of their parents, and if parental control falters, the State must play its part as parens patriae").

228. Roger J.R. LeVESQue, Adolescents, SeX, AND the LAW: PrePARING Adolescents for RESPONSIBLE CITIZENSHIP 40 (2000).

229. Rustad \& Koenig, supra note 207, at 80 (emphasis added) (quoting Alfred L. Snapp \& Son, Inc. v. Puerto Rico ex rel. Barez, 485 U.S. 592, 600 (1982)).

230. See Prince v. Massachusetts, 321 U.S. 158, 168 (1944) ("A democratic society rests, for its continuance, upon the healthy, well-rounded growth of young people into full maturity as citizens.").

231. Curtis, supra note 180, at 902 ("[T] he purpose of such action was not solely to foster the well being of the child, but to protect the security and well being of the state.").

232. LaShanda Taylor, A Lawyer for Every Child: Client-Directed Representation in Dependency Cases, 47 FAM. CT. REV. 605, 608 n.19 (2009) ("The state is the supreme guardian of all children within its jurisdiction and state courts have the inherent power to intervene to protect the best interests of children whose welfare is jeopardized.").

233. Kristina v. Foehrkolb, Comment, When the Child's Best Interest Calls for It: Post-Adoption Contact by Court Order in Maryland, 71 MD. L. REV. 490, 493-94 (2012) (internal quotations omitted). 
in the nature of parens patriae." ${ }^{234}$ Thus, under parens patriae authority, the court has a duty to protect "the best interests of children in actions before the court, even if the Legislature has not determined what the best interests require in a particular situation." 235

Exercising this authority, courts have refused to enforce parental directives in a number of contexts when those decisions are incompatible with a child's best interest. One such example relates to settlement agreements, wherein courts are free to reject "provisions of agreements between spouses affecting custody, visitation, child support, and relocation of a custodial parent." ${ }^{236}$ Consider for instance the case of Delamielleure v. Belote, ${ }^{237}$ in which a divorcing couple included a provision in the settlement agreement stating that the child's domicile would be determined by the mother. ${ }^{238}$ In that same provision, both parties waived a requirement under state law that restricted a custodial parent's ability to move the child more than 100 miles away. ${ }^{239}$ Nonetheless, when the mother subsequently attempted to move the child out of state, the father brought a claim arguing that the waiver provision was invalid. ${ }^{240}$ The court agreed, refusing to enforce that portion of the agreement and holding that "parenting time is not merely a right of the parent, but also a right of a child and thus ... even if the parties' rights could be and were waived, the child's rights - and the parents' obligations - were not and could not be waived by the divorce settlement."241

Courts have likewise used their parens patriae authority in other contexts - for example, in refusing to enforce liability waivers signed by a child's parent. In Cooper v. Aspen Skiing Co. ${ }^{242}$ a seventeen-year-old

234. In re D.S., 763 N.E.2d 251, 261 (Ill. 2001) (internal quotations omitted). In terms of how parens patriae operates in the other branches of government, the court's opinion offers some examples. For instance, the court mentioned legislation designed to "to secure the best interests of the minor and the community," and regarding the executive branch, the court referenced the discretion of the State's Attorney to prosecute cases relating to child maltreatment. Id. at 258-59.

235. E.N.O. v. L.M.M., 711 N.E.2d 886, 890 (Mass. 1999); see also Margaret S. Thomas, Parens Patriae and the States' Historic Police Power, 69 SMU L. REV. 759, 797 (2016) ("This is true even in the absence of statutory authority for the parens patriae power: lower courts continue to rely instead on the common law sovereignty narrative articulated by the Supreme Court when statutory authority fails.").

236. Bix, supra note 34, at 260; see also Dewhurst v. Dewhurst, 5 A.3d 23, 26 (Me. 2010) ("The court must independently evaluate a settlement agreement involving minor children to ensure custody matters are resolved according to the children's best interest.").

237. 704 N.W.2d 746 (Mich. Ct. App. 2005).

238. Id. at 748 .

239. Id.

240. Id.

241. Id. at 749 ("[T]his Court has taken a dim view of agreements purporting to sign away the rights of a child.") (quoting Van Laar v. Rozema, 288 N.W.2d 667, 669 (Mich. Ct. App. 1980)).

242. 48 P.3d 1229 (Colo. 2002). 
boy brought suit after being severely injured while taking skiing lessons from the defendant. ${ }^{243}$ The defendant sought summary judgment on the basis that, prior to that incident, the child's mother had signed a liability waiver. ${ }^{244}$ To illustrate, consider a New York case in which a couple had formalized an adoption using a Mexican court. ${ }^{245}$ In applying for the issuance of a New York birth certificate, the court refused, finding that the Mexican court lacked jurisdiction, despite the fact that both the birth mother and the adoptive parents had consented. ${ }^{246}$ In so ruling, the court held that, in New York, "the welfare of its children is one of its strongest public policies. To lend an imprimatur to an adoption, predicated upon insufficient jurisdictional foundations and a questionable perfunctory examination into the interests of the child, would be an inexcusable abdication of the State's role as parens patriae."247

In sum, despite owing its existence to a typographical error, ${ }^{248}$ parens patriae has secured not only a crucial but an expansive role in the law of domestic relations within the United States, conferring upon courts an inherent right and an affirmative duty to protect children from the actions of their parents. In essence, parens patriae, "gives the state authority to serve as a substitute parent and ultimate protector of children's interests." ${ }^{249}$ And, in carrying out that role, "the right of parents . . . may be enlarged, restrained, and limited as the wisdom or policy of the times may dictate." ${ }^{250}$

\section{WHEN DISINHERITANCE BECOMES A FORM OF ABUSE OR NEGLECT}

Just as courts invoke their parens patriae authority when refusing to enforce other parental directives, ${ }^{251}$ it is the position of this Article that courts must likewise refuse to enforce testamentary schemes that

\footnotetext{
243. Id. at 1230 .

244. Id.

245. Barry E. v. Ingraham, 371 N.E.2d 492 (N.Y. 1977).

246. Id. at 496 (" $[\mathrm{N}]$ o more than the naked and inadequate 'jurisdictional' facts recited in the Mexican order were produced.").

247. Id. at 496.

248. See supra notes $183-194$ and accompanying text.

249. Kindred, supra note 33, at 526.

250. Douglas R. Rendleman, Parens Patriae: From Chancery to the Juvenile Court, 23 S.C. L. REV. 205, 221 (1971) (quoting United States v. Bainbridge, 24 F. Cas. 946 (C.C.D. Mass. 1816)); see also Joan Neisser, Disclosing Adolescent Suicidal Impulses to Parents: Protecting the Child or the Confidence?, 26 IND. L. REV. 433, 466 (1993) ("[T]he state's parens patriae interest in protecting children allows it to curtail the rights of parents when their actions are harmful to their child."); Dayna B. Royal, Jon \& Kate Plus the State: Why Congress Should Protect Children in Reality Programming, 43 AKRON L. REV. 435, 486 (2010) ("Parens patriae authority enables the state to curtail parental control in various arenas for a number of legitimate reasons.").
}

251. See supra notes 236-248 and accompanying text. 
constitute parental abuse or neglect. To protect against such harm, this Article proposes that, when it comes to "vulnerable child heirs"- defined here as minor children, adult disabled children who remain dependent, and adult children who were abused by the testator parent - any attempts by a parent at disinheritance should fail unless it can be shown that the parent has otherwise provided for the child in an amount sufficient to satisfy the parent's obligation.

In making such a proposal, it may initially seem a radical departure from the American law of succession or, more specifically, from the venerated role testamentary freedom has been permitted to occupy within that sphere. For that reason, this Part first explains why reform is necessary and why parens patriae is the appropriate vehicle for implementing such reform, before discussing the specifics of how the proposal would operate for each of the three categories of children. Part IV will then focus on how such an approach might operate, looking specifically at the children who would be protected from disinheritance, what evidence would be necessary to prove abuse or neglect in the testamentary context, and what would be the appropriate remedy.

\section{A. Vulnerable Child Heirs and the Evolving Family}

Few would disagree that the law should protect children from abuse and neglect. Indeed, protecting children from these harms is unquestionably a compelling state interest, and the law is replete with rules designed to do just that. ${ }^{252}$ As detailed earlier, however, the law of succession is a notable exception. ${ }^{253}$ Shielded by testamentary freedom, a parent can effectively use death as a way to financially abandon a child and instead make the child a ward of the state, which is then responsible for any resulting financial harms the disinheritance might have caused. Thus, American law affords a testator the right to not only "choose who will succeed to things of value left behind at death, ${ }^{, 254}$ but to do so in a way that is harmful to the testator's child. This approach, of course, is nothing new-the United States has always permitted parents to disinherit

252. See Laura Oren, The State's Failure to Protect Children and Substantive Due Process: Deshaney in Context, 68 N.C. L. REV. 659, 712 n.401 (1990) ("Children are the object of legislative and judicial solicitude that has created protective structures of one kind or another.").

253. See supra section I.A.

254. Lawrence M. Friedman, The Law of Succession in Social Perspective, in DEATH, TAXES AND FAMILY PROPERTY, supra note 57, at 9, 12; see also Ray D. Madoff, A Tale of Two Countries: Comparing the Law of Inheritance in Two Seemingly Opposite Systems, 37 B.C. INT'L \& COMP. L. REV. 333, 334 (2014) ("Freedom of testation gives people the ability to distribute their property at death as they wish — even to the exclusion of their family members and even if the decedent's children become wards of the state as a result of the disinheritance."). 
their children. ${ }^{255}$ Nonetheless, given that children are increasingly at risk of disinheritance and some of these children are particularly vulnerable to economic harm, a change in the law is now required for several reasons.

First, the American family is evolving and laws that might once have protected children from the financial harms of disinheritance have become increasingly obsolete. As noted earlier, one of the justifications for child disinheritance resides in the belief that bequests to the testator's spouse will provide a "trickle down" benefit for the testator's children given that the surviving spouse remains subject to state laws requiring parents to support their children. ${ }^{256}$ The problem with this rationale, however, is that it assumes that the testator's surviving spouse, in fact, enjoys a parentchild relationship with the testator's surviving children. With the rise in divorce, remarriage, and cohabitation, one can no longer assume that to be true. ${ }^{257}$ Instead, at the time of a testator's death, his or her children are less likely to be the children of the testator's spouse. ${ }^{258}$ In such situations, the testator's spouse would have "no legal obligation and may have little emotional incentive to use her elective share for their benefit.",259

Additionally, with these changes to the American family, testators may disinherit a child not simply because they have moved on to a new relationship, but out of spite for past, failed relationships. ${ }^{260}$ As Ralph Brashier explains, "[f]amilies frequently splinter and parents form new attachments and nurse old grudges toward former family members ... [and, thus, ] the incidence of child disinheritance is likely to increase." 261 For example, "following a bitter divorce dispute, the noncustodial parent may disinherit his minor child as one last slap at the

255. See supra section I.A.

256. See supra notes 102 and accompanying text.

257. See Brashier, Modern Family, supra note 18, at 163 ("When 'family' meant two heterosexual, married parents and their children, unaffected by divorce and remarriage, the elective share system was more effective and thus more justifiable than it is now.").

258. See Asadorian, supra note 22, at 121 ("In these situations, money left to the surviving spouse is not money that is, in essence, indirectly left to the minor children."); Brashier, Modern Family, supra note 18, at 163 ("Today ... large numbers of minor children are denied this indirect protection from disinheritance because in our multiple marriage society the surviving spouse often is not the parent of the testator's minor children.").

259. Brashier, Modern Family, supra note 18, at 116 ("Moreover, she quite often will have minor children who are not those of the testator; ironically, the conduit effect will inure to their benefit (because of her legal obligation of support) while the testator's own disinherited children are excluded."); see also Waggoner, supra note 116, at 233 ("When a decedent is survived by children not descended from the surviving spouse, or by children of the surviving spouse not descended from the decedent, the decedent has a surviving spouse with divided loyalties and, hence, a spouse who is a less reliable conduit.").

260. See Asadorian, supra note 22, at 108 (noting that "parents may disinherit their children out of anger or spite for the custodial parent or child").

261. BRASHIER, INHERITANCE LAW, supra note 132, at 103. 
custodial parent or the child." ${ }^{262}$ Thus, the law must recognize that children now enjoy varying levels of legal protection from disinheritance based largely on the relationship histories of their parents. As one commentator has concluded: "The law should not implicitly sanction this disproportionate treatment of children who, through no fault of their own, do not reside with both of their biological parents." 263

Although some courts have attempted to deal with this problem through expansive application of principles like undue influence, fraud, and capacity, ${ }^{264}$ the law requires a solution that is more consistent and more effective. Those principles were never intended to shield children from the harms of disinheritance but were instead aimed at safeguarding testamentary intent. ${ }^{265}$ The fact that currently no protections exist against child disinheritance does not mean that the best solution is to, at the judge's discretion, expand other principles of succession law to fill that void. ${ }^{266}$ Instead, the law requires a more intentional approach —one that depends, not on a creative remedy that a judge may or may not impose, but one that is both mandated by the law and also tailored to protect those most in need. Currently, by permitting testators to indiscriminately disinherit children, some of our country's most vulnerable citizenscitizens the state has an affirmative duty to protect-are left to the mercy of the dead hand. Quite simply, those children deserve more meaningful protections than that provided by the haphazard use of inapposite legal doctrines.

After all, disinheritance can be quite devastating. Other countries are so concerned about these harms that they have made it virtually impossible for testators to disinherit any of their children. ${ }^{267}$ This Article does not go that far; instead, it advocates for an approach that focuses on three categories of children: minor children, adult children who remain dependent upon their parents as a result of a disability, and adult survivors of child abuse. As discussed below, the children who occupy these three

262. Brashier, Protecting the Child, supra note 16, at 9-10; see also Kujawinski v. Kujawinski, 376 N.E.2d 1382, 1391 (Ill. 1978) ("[T] dive divorced parent may harbor animosity toward a former spouse, which disposition might obscure the natural tendency to provide in a will for their mutual children.").

263. Asadorian, supra note 22, at 121.

264. See supra notes 120-127 and accompanying text.

265. See Leslie, supra note 53, at 236-37 ("[C]ourts faced with an offensive will often use other doctrines ostensibly designed to ascertain whether the testator formulated testamentary intentdoctrines such as capacity, undue influence and fraud - to frustrate the testator's intent and distribute estate assets to family members.").

266. See FriEDMAN, supra note 66, at 96 (noting that "[w]hether a court actually finds undue influence depends on the facts of each case-plus social norms and the court's own prejudices and opinions. The cases thus are very dependent on time and place").

267. See supra section I.B. 
categories are the most susceptible to harm should they face disinheritance. After all, for minor children and disabled adult children, inheritance may be the only thing preventing them from becoming wards of the state. The same is likely true for adult survivors of child abuse given the financial, educational, and health consequences they typically suffer as result of having been abused by the very parent now attempting to disinherit them. ${ }^{268}$ Thus, for a state to deny these individuals any hope of protection would run afoul of its parens patriae duty "to protect children whose vulnerable lives or psychological well-being may have been harmed or may be seriously endangered by a neglectful or abusive parent." ${ }^{269}$

\section{Minor Children}

Courts and legal commentators alike frequently refer to minor children as our nation's most vulnerable citizens - a characterization that stems from the innate differences between children and adults. As Elizabeth Scott explains,

children are dependent on others - initially, for survival and, as they grow, for the care that will enable them to mature to adulthood. This dependency means that others provide for their basic needs - for food, shelter, health care, affection, and education-so that they may become healthy, productive members of society. Children also lack the capacity to make sound decisions. Because of their immature cognitive development, children are unable to employ reasoning and understanding sufficiently to make choices on the basis of a rational decision-making process .... This decision-making immaturity warrants giving others authority over important decisions affecting children's lives. ${ }^{270}$

For those reasons, the law imposes a number of duties upon parents to support and protect their children with the basic understanding that "each parent has an obligation to nurture his [or her] children until they reach

268. See infra section III.A.3.

269. N.J. Div. of Youth \& Family Servs. v. F.M., 48 A.3d 1075, 1090 (N.J. 2012); see also Late Corp. of the Church of Jesus Christ of Latter-Day Saints v. United States, 136 U.S. 1, 57 (1890) (noting that "parens patriae ... . is a most beneficent function, and often necessary to be exercised in the interests of humanity, and for the prevention of injury to those who cannot protect themselves").

270. Elizabeth S. Scott, The Legal Construction of Adolescence, 29 HOFSTRA L. REV. 547, 550 (2000). 
adulthood." ${ }^{271}$ And, as detailed earlier, when parents fail to live up to those responsibilities, parens patriae permits the state to intervene. ${ }^{272}$

Accordingly, "[t]he importance of parental support of minor children has both moral and economic dimensions." ${ }^{273}$ Citing those interests, legal scholars have taken particular issue with a parent's ability to disinherit minor children. ${ }^{274}$ As one commentator put it, "[w] hen we recognize that the testator's estate will do him no good in death, his act of disinheriting his minor child seems to be the ultimate abnegation of societal and moral responsibility." ${ }^{275}$ The minor child is, after all, "a dependent who would not exist but for the presence of the testator himself."276 Further, dependent children play no role in family formation given that they cannot "voluntarily or knowingly establish the family relationship with the testator." 277

What makes the minor children particularly vulnerable to the harms of disinheritance is their inability to safeguard their interests. Adult family members who might fear disinheritance-including spouses, were they not already protected from disinheritance ${ }^{278}$ - are capable of "acquiring, earning, managing, and protecting significant property interests" as a means of protecting themselves from the financial harms of disinheritance. ${ }^{279}$ Minor children possess no such ability but instead are at the mercy of their parents. ${ }^{280}$ In fact, minor children typically do not even

271. Brashier, Protecting the Child, supra note 16, at 4; see also Accent Serv. Co. v. Ebsen, 306 N.W.2d 575, 576 (Neb. 1981) ("[E]ven in the absence of statute, parents are under a legal as well as a moral obligation to support, maintain, and care for their children, the basis of such a duty resting not only upon the fact of the parent-child relationship, but also upon the interest of the state as parens patriae of children and of the community at large in preventing them from becoming a public burden."); Taite, supra note 31, at 325 ("Mandating financial responsibility for the care of children during one's lifetime is without question.").

272. See supra section II.B.

273. Asadorian, supra note 22, at 103.

274. See, e.g., Batts, supra note 1, at 1255 (proposing that "when there are surviving minor or dependent children, their needs must be met before" other family members and dependents); Brashier, Protecting the Child, supra note 16, at 3 (characterizing the lack of protection for minor children as "particularly disconcerting in a country that pays great lip service to ensuring the well-being of its youth"); Brennan, supra note 101, at 126 (advocating for "more legislation to benefit dependent surviving minors") .

275. Brashier, Protecting the Child, supra note 16, at 21 ("The history and policy of testamentary freedom are insufficient reasons for continuing to permit the disinheritance of one's minor children.").

276. Id. at 20 .

277. Batts, supra note 1 , at 1200.

278. See supra notes $75-80$ and accompanying text.

279. Brashier, Modern Family, supra note 18, at 86.

280. See Jan E. Rein, A More Rational System for the Protection of Family Members Against Disinheritance: A Critique of Washington's Pretermitted Child Statute and Other Matters, 15 GonZ. L. REV. 11, 47 (1979) ("Spouses, after all, enter into the husband-wife relationship voluntarily at an age when they can protect their interests while children do not volunteer to be brought into the parentchild relationship thrust upon them at birth."). 
possess the reciprocal right to disinherit their parents: "in most states a child under eighteen cannot make a will, [and thus] the child cannot disinherit her parent. Ironically, the effect is that the parent receives the benefit of forced heirship which is denied to his child." 281

\section{Adult Children Who Remain Dependent Due to Disability}

Because an adult child is typically more capable of protecting their own interests, the state's parens patriae authority greatly diminishes when a child reaches adulthood. ${ }^{282}$ For that reason, at least one scholar has opined that "disinheritance of one's adult children is much less objectionable than disinheritance of one's minor children who are as yet incompetent to provide for themselves." ${ }^{283}$ However, not all adult children are similarly situated, and some continue to fall into the category of vulnerable persons that the doctrine of parens patriae was designed to protect. Within this category are adult children who remain dependent upon their parents as a result of a disability. As one commentator describes, "[1]ike minor children, adult children who are incapable of self-care because of mental or physical disabilities are vulnerable and in special need of their parents' time and attention." 284

Blackstone himself wrote that "[n]o person is bound to provide a maintenance for his issue unless where the children are impotent, either through infancy, disease or accident[.]"285 Today, the majority of states agree, requiring parents to support adult children who, as a result of a disability that occurred during the child's minority, remain dependent upon the parent. ${ }^{286}$ One of the earliest states to recognize such a duty was Kentucky, where in 1908, the highest court of the state recognized that "[a]n adult child may from accident or disease be as helpless and

281. Brashier, Modern Family, supra note 18, at 170.

282. See, e.g., Vincent A. Cirillo, Curtis v. Kline: The Pennsylvania Supreme Court Declares Act 62 Unconstitutional - A Triumph for Equal Protection Law, 34 DUQ. L. REV. 471, 487 n.107 (1996) ("Regulating filial relationships between adults when it comes to matters such as custody or support of minor children can be rationalized purely on the basis of the child's minority and the doctrine of parens patriae. This is not applicable, however, in matters between parents and adult children.").

283. Brashier, Protecting the Child, supra note 16 , at 8.

284. Jennifer H. Kaplan, Note, Administrative Law-Navarro v. Pfizer Corporation: Too Much Disregard and Too Little Deference in Defining "Disability" Under the Family and Medical Leave Act, 25 W. NEW ENG. L. REV. 263, 268 (2003).

285. 1 William Blackstone, COMMENTARIES ON THE LAWS OF ENGLAND 437 (1765).

286. See Sande L. Buhai, Parental Support of Adult Children with Disabilities, 91 MINN. L. REV. 710,721 (2007) (noting that only nine states follow "the common law rule that does not extend a parent's duty beyond the child's minority, regardless of existing or subsequent disabilities"); Tate, supra note 8, at 162 ("Most states require parents to support a disabled adult child, at least if the disability arose before the child reached the age of majority."). 
incapable of making his support as an infant." ${ }^{287}$ Accordingly, the court held that there was "no difference in principle between the duty imposed upon the parent to support the infant and the obligation to care for the adult, who is equally, if not more, dependent upon the parent." 288

Although there is some debate regarding what forms of disability justify the legal duty to continue support past the age of minority and how long such an obligation should extend, ${ }^{289}$ the point here is merely that, once a parent has assumed that duty vis-à-vis an adult child, that child becomes particularly vulnerable should the parent die without leaving the child an adequate source of support. Adult disabled children who do find themselves disinherited are likely to rely on the state for assistance ${ }^{290}$ an externality that, as explained below, ${ }^{291}$ other exceptions to testamentary freedom strive to prevent.

It should be noted, however, that some parents disinherit adult, disabled children not out of spite or malice, but out of kindness and practicality. As Judith McMullen explains,

disinheritance is sometimes regarded by parents as the lesser of two evils. When disabled adult children have financial needs beyond what a parent could provide, the parent may allow the child to be emancipated, and the child will be eligible for public benefit programs. However, benefit programs have strict eligibility requirements. Any financial windfall, such as an inheritance, will make the child ineligible for benefits programs. Money from a support trust will have the same effect. In addition, any funds received by the disabled child may be immediately targeted for repayment of past expenses paid by the state. ${ }^{292}$

Such concerns would, of course, exist only for those adult children receiving certain benefits. Nonetheless, should states try to protect those children from disinheritance, both the state and federal government may need to revisit eligibility requirements for these programs, focusing on how to prevent parents from using disinheritance as a means to shift the entire cost of their child's care onto the government yet, at the same time,

287. Crain v. Mallone, 113 S.W. 67, 68 (Ky. 1908).

288. Id.

289. See Buhai, supra note 286, at 712 (questioning whether courts should "recognize a legally enforceable requirement that parents support their adult children with disabilities indefinitely regardless of the type of disability, the age of onset, or the family relationship").

290. See Katherine B. McCoy, Note, The Growing Need for Third-Party Special Needs Trust Reform, 65 CASE W. RES. L. REV. 461, 478 (2014) (noting that "many disabled individuals cannot maintain an adequate quality of life without relying" at least in part, on government assistance).

291. See infra section III.B.2.

292. McMullen, supra note 102, at 360 n.107. 
how to ensure that inheritance cannot thwart an individual's ability to continue receiving essential benefits.

\section{Adult Survivors of Child Abuse}

It is unclear the extent to which abusive parents resort to disinheritance as a means of inflicting even greater abuse on their children. A survey of prior cases provides little guidance given that "most cases of child disinheritance do not reach the courts, because the children (or their representatives) know that the testator's act is legally permissible even when morally reprehensible. ${ }^{~} 293$ Nonetheless, instances where children have alleged disinheritance as a form of parental abuse do exist. The facts of Merrick v. Helter, ${ }^{294}$ discussed in the Introduction, provide one such example. ${ }^{295}$ Perhaps the most famous case, however, involves the legendary screen actress Joan Crawford. In the 1940s, Crawford adopted two children, Christina and Christopher. ${ }^{296}$ When Crawford died in 1977, she left a will that disinherited both of them: "It is my intention to make no provision herein for my son Christopher or my daughter Christina for reasons which are well known to them." ${ }^{" 297}$ Subsequently, Christina Crawford wrote Mommie Dearest, a best-selling book in which she detailed years of abuse she and Christopher had endured at the hands of their mother. ${ }^{298}$ In that book, Christina explained the connection between the disinheritance by her mother and the earlier abuse: "She had gone out of this life carrying all the years of hatred and cruelty and violent rage with her, clutching at the torment of it as though it were just yesterday."299

Regardless of the frequency with which abusive parents disinherit their children, the more salient point is how particularly vulnerable those children are to the harms of disinheritance. To understand why, one need only consult the numerous studies that have documented the debilitating harms that result from child abuse - harms that can last a lifetime. Social

293. BRASHIER, INHERITANCE LAW, supra note 132, at 105.

294. 500 S.W.3d 671, 672 n.1 (Tex. App. 2016).

295. See supra notes $2-7$ and accompanying text.

296. See Elizabeth C. Hirschman, Motherhood in the Movies-1942 to 2010: Social Class Mobility and Economic Power, in MOTHERHOOD, MARKETS AND CONSUMPTION: THE MAKING OF MOTHERS IN CONTEMPORARY WESTERn CUlTURES 17, 24 (Stephanie O'Donoghue et al., eds. 2016).

297. See Charlotte Chandler, Not the Girl Next Door: JoAn Crawford, A Personal BIOGRAPHY 281 (2008). She did, however, leave an estate valued at \$2 million and bequeathed her other two adopted children more than $\$ 75,000$ each. Id.

298. Christina CRAWFORD, MOMMIE DEAREST (1978).

299. Id. at 672 . The children did challenge the will and ultimately received a small amount. See LAWRENCE J. QuirK \& William Schoell, JoAn CraWford: THE ESSENTIAL Biography 253 (2002) ("The estate lawyers gave Christina a settlement of approximately $\$ 55,000$, but after paying off her own lawyers and splitting the rest with her brother, she got little more than ten thousand, a far cry from what she'd been hoping for."). 
scientists have broken these harms down into three categories: physical health consequences, psychological consequences, and behavioral consequences. ${ }^{300}$ In terms of physical harms, adults who were abused as children - as compared to the general population - have been shown to suffer higher rates of, inter alia, high blood pressure, diabetes, vision problems, heart attacks, bowel disease, and stroke. ${ }^{301}$ Psychologically, they also suffer greater incidences of post-traumatic stress, anxiety, attachment disorders, and depression. ${ }^{302}$ Finally, adult survivors of child abuse exhibit a number of behavioral consequences, including drug and alcohol dependency, "juvenile delinquency leading to adult criminality[,] ${ }^{303}$ lower educational attainment, ${ }^{304}$ and unemployment. ${ }^{305}$

For adult survivors of child abuse who might be suffering from any of these harms, disinheritance would be particularly harmful given that inheritance might be all the child has to help deal with those consequences - consequences that arose from the harms inflicted upon the child during his or her minority. As noted earlier, the state has a particular interest in protecting minor children from such abuse and neglect. ${ }^{306}$ Although incapable of protecting all children at all times from abuse, the state can and should refrain from perpetuating that abuse when it comes in the form of a testamentary document the state is being asked to probate. Arguably, the state may even be required to do so. After all, although reasonable minds might disagree on the precise scope of parens patriae, seemingly all would agree that the state is precluded from acting in such a way as to exacerbate the abuse of a child. ${ }^{307}$

300. See U.S. Dep'T of Health \& Human Servs., Child's Bureau, Child Welfare INFORMATION GATEWAY, CHILDREN'S BUREAU LONG-TERM CONSEQUENCES OF CHILD ABUSE AND NEGLECT FACTSHEET (2019), https://www.childwelfare.gov/pubpdfs/long_term_consequences.pdf [https://perma.cc/HHH9-BHHX].

301. Id. at 2 .

302. Id. at 3; see also KATHLEen A. Kendall-TAcKetT, The Hidden Feelings OF Motherhood: Coping With Stress, Depression, AND Burnout 138 (2001) ("Many adult survivors of physical, sexual or severe emotional abuse show symptoms of PTSD.").

303. CHILD WELFARE INFORMATION GATEWAY, supra note 300, at 4.

304. See Kristen W. Springer et al., The Long-term Health Outcomes of Childhood Abuse: An Overview and a Call to Action, 18 J. GEN. INTERNAL MED. 864, 866-67 (2003) (noting the "substantial body of literature linking childhood abuse with poor educational outcomes").

305. See Ruth Gilbert et al., Burden and Consequences of Child Maltreatment in High-Income Countries, 373 LANCET 68, 74 (2009) (describing studies that found that "significantly more of the abused and neglected individuals were in menial and semi-skilled occupations than were controls $(62 \%$ vs $45 \%)$ at 29 years of age, and fewer had remained in employment during the past 5 years (41\% vs 58\%)").

306. See supra section II.

307. See, e.g., DeShaney v. Winnebago Cty. Dep't of Soc. Servs., 489 U.S. 189, 207 (1989) (Brennan, J., dissenting) (citing prior cases supporting that proposition) (noting that "a State may be found complicit in an injury even if it did not create the situation that caused the harm"). Although the majority in that opinion concluded "that a State's failure to protect an individual against private 


\section{B. Parens Patriae Protects Vulnerable Child Heirs Without Unduly Restricting Testamentary Freedom}

As discussed above, reform is necessary not only due to the changing American family, which puts a growing number of children at risk of disinheritance, but also the magnitude of harm disinheritance can cause certain classes of children. It is the position of this Article that an approach based on parens patriae would allow for a solution to these problems that is more consistent with the existing law of succession. Again, American law is very much concerned with preserving the rights of testators to control how their property will be distributed after their death. ${ }^{308}$ In this regard, the law appears to reflect public opinion. ${ }^{309}$ Consider, for instance, a study that asked Americans living in five different states the following question: "Should the law limit inheritance to either relatives, to friends of long standing, or to organizations to which an individual has had a long time connection or should there be no restrictions at all on the way a person distributes his property?" 310 Eighty-nine percent of respondents said there should be no restrictions whatsoever. ${ }^{311}$ Interestingly enough, however, when those same individuals were questioned about more specific situations, their commitment to testamentary freedom waned. For example, when asked whether testators should be permitted to leave their estate to a pet, fifty-four percent of respondents said no. ${ }^{312}$

A similar dynamic emerges when Americans are surveyed about child disinheritance. In a study that asked participants whether the law should permit a testator parent to devise property to individuals outside of the family and leave nothing to the testator's children, over ninety-three percent responded that a parent should not have the right to disinherit children under twenty-one years of age. ${ }^{313}$ Even when asked about adult children, over sixty-three percent responded that a testator should not be permitted to disinherit those children over the age of twenty one. ${ }^{314}$

violence simply does not constitute a violation of the Due Process Clause," it also acknowledged that the state in that case had not taken any action that would render the child in question "more vulnerable" to harm. Id. at 197.

308. See supra section I.A.

309. See FRIEDMAN, supra note 66, at 46 (describing testamentary freedom as both a "fundamental principle of law" and a "fundamental social norm").

310. Mary Louise Fellows, Rita J. Simon \& William Rau, Public Attitudes About Property Distribution at Death and Intestate Succession Laws in the United States, 1978 AM. B. FOUND. RES. J. 319, 335 (1978) (emphasis omitted).

311. Id. at 336 .

312. Id.

313. See Julius Cohen, Reginald A.H. Robson, \& Alan Bates, Parental Authority: The COMMUNITY AND THE LAW 77, tbl.12 (1958).

314. Id. 
Results like these have led one commentator to conclude that, at the very least, "Americans would be amenable to laws that would specifically outlaw the disinheritance of minor children." 315

Regardless, this Article is not proposing such a sweeping change in the law. Instead, this Article is advocating for an approach whereby a court, using its inherent parens patriae authority, will not enforce a testator's attempt to disinherit a vulnerable child heir if that disinheritance would subject the child to abuse or neglect. By taking this approach, testators will retain much of the testamentary freedom that the law currently provides, and the few limitations it does impose are consistent with the existing exceptions to testamentary freedom.

\section{Preserving Testamentary Freedom}

As an initial point, this proposal would largely preserve testators' ability to disinherit most children. The proposal only covers those children who qualify as a vulnerable child heir, which again is limited to minor children, adult children who remain dependent on their parents as a result of a disability, and adult children who were abused by the testator parent during their minority. Even then, a court would still enforce the testator's attempt at disinheritance so long as there was evidence that the testator had otherwise discharged his or her obligations toward the child in question. Given these two limitations, this proposal is far less intrusive than the systems developed by other countries to protect children from disinheritance.

First, the proposal only applies to a discrete subset of children. Unlike forced heirships where all children regardless of age or need are guaranteed a certain percentage of their parent's estate, ${ }^{316}$ the only children who could even attempt to claim the benefit of this proposal are limited to those who fall into these three categories. Similarly, this proposal avoids the problem of the wide discretion and uncertainty that exists in family maintenance statues, whereby judges are permitted to consider petitions by any of the testator's children (and, in some cases, dependents) and then substitute their own decision about how a testator should have directed the disposition of the property. ${ }^{317}$ In both of these international approaches, a testator is effectively prevented from ever disinheriting a child. This proposal, on the other hand, continues to provide parents the option of disinheriting most children, subject only to limited exceptions. In advocating for such an approach, this proposal is

315. Asadorian, supra note 22, at 125.

316. See supra section I.B.1.

317. See supra section I.B.2. 
mindful of the traditional justifications behind permitting child disinheritance, recognizing that many are founded upon important policy considerations. ${ }^{318}$ At the same time, this proposal seeks to curb parental disinheritance when, regardless of the motivation, the disinheritance would result in abuse or neglect.

Second, even among those children protected by this proposal, the law would only disregard an attempt at disinheritance if the parent had otherwise failed to meet his or her obligations to the child. Thus, unlike the forced heirship model, which provides children with a set percentage regardless of need, this proposal would instead affirmatively take into account the broader actions of the testator. Thus, the focus would not rest simply upon whether the testator parent failed to provide for the child in whatever testamentary document the testator executed, but whether the parent had discharged these obligations in some other manner. For instance, a parent may attempt to provide for the child in another wayperhaps through an inter vivos disposition ${ }^{319}$ or through a sufficient bequest to the child's other legal parent, someone who would in fact have a legal duty to provide for the child. ${ }^{320}$

\section{Promoting Consistency with Current Exceptions}

Regardless of how minimally this proposal might curtail testamentary freedom, it is a curtailment all the same. Nonetheless, it is the contention of this Article that, aside from being necessary, this exception is likewise consistent with the existing limitations American law has imposed upon the dead hand. As Lawrence Friedman points out in his book, Dead Hands: A Social History of Wills, Trusts, and Inheritance Law, "[o]ur legal system allows the dead to control the living," but only "up to a point." ${ }^{2} 21$ More specifically, Daniel Kelly has noted that "[w]hile generally permitting the intentional disinheritance of children, American succession law does restrict the freedom of testation in other situations involving externalities." ${ }^{322}$ It does so with the understanding that, in those

318. See supra notes 100-110 and accompanying text.

319. See Mary M. Wenig, The Marital Property Law of Connecticut: Past, Present and Future, 1990 WIS. L. REV. 807, 855 (1990) (listing a number of testamentary substitutes individuals can effectuate during their life: "inter vivos trust with reserved life estate and power of appointment; revocable inter vivos trust; life insurance; . . . IRAs and nonqualified retirement plans; pay-on-death U.S. bonds and other P.O.D. contractual benefits; and even a deed deliverable to grantee only on death of grantor.").

320. See BRASHIER, INHERITANCE LAW, supra note 132, at 105 ("A parent who disinherits his minor child may provide for the child outside the probate process through inter vivos trusts, life insurance policies, payable-on-death accounts, and the like.").

321. FRIEDMAN, supra note 66, at 125.

322. Kelly, supra note 35, at 1162. 
situations, "effectuating donative intent might be inconsistent with maximizing social welfare." ${ }^{~} 23$

One such external cost involves the disinheritance of one's spouse. As noted earlier, in every state but one the surviving spouse "is the only person in the family who cannot be disinherited." 324 A number of justifications have been put forth for this protection, including the "economic partnership of marriage theory" 325 and the mutual duties of support that spouses owe one another. ${ }^{326}$ The primary justification, however, appears to be the state's interest in preventing the surviving spouse from becoming a ward of the state. ${ }^{327}$ Or, as one court put it, "[t]he legislative purpose behind the elective share statute is to protect the family unit from becoming society's ward by preventing impoverishment of the surviving spouse." 328

Of course, the family unit also encompasses children, and thus, the rationales for preventing spouses from becoming wards of the state should apply with equal force to at least some categories of children. Furthermore, an individual "might reduce or exclude his or her allocation to a spouse or children, depending on public support to take up the slack. This externality might justify a stipulation that some minimum fraction of property be given to spouses and children." 329 The most frequent justification for not including children in this scheme is the assumption that the surviving spouse would have a legal duty to support minor children and, thus, the elective share would result in a "trickle down" benefit to the children. ${ }^{330}$ Again, however, with the changing American family, that assumption is increasingly at odds with reality given that increased incidences of divorce, remarriage, and cohabitation have made it such that the testator's surviving spouse is less likely to be the second parent to the testator's surviving children. ${ }^{331}$

\section{Id. at 1161.}

324. FRIEDMAN, supra note 66 , at 181 ; see also supra notes $75-80$ and accompanying text.

325. Batts, supra note 1, at 1199; see also Taite, supra note 31, at 341 ("Protecting spouses from disinheritance is based.... [in part] on the partnership theory, [which] is founded on the principle that parties to the marriage contribute in various ways to the success of the marriage.").

326. See Waggoner, supra note 116, at 251 ("Another theoretical basis for elective-share law is that the spouses' mutual duties of support during their joint lifetimes should be continued in some form after death in favor of the survivor.").

327. See Batts, supra note 1, at 1199 (noting the "overriding state concern that the surviving spouse does not become a ward of the state").

328. Williams v. Williams, 517 S.E.2d 689, 691 (S.C. 1999) (citing Berkebile v. Outen, 426 S.E.2d 760, 763 (S.C. 1993)).

329. SHAVELL, supra note 55, at 65 (emphasis added).

330. See supra notes 101-102 and accompanying text.

331. See supra notes 258-263 and accompanying text. 
Children today are arguably even more deserving than spouses of being protected against disinheritance given the inability of children to safeguard their own interests:

The surviving spouse is an autonomous, competent adult who voluntarily entered into a family relationship with the testator. Moreover, that surviving spouse has the ability to protect herself from disinheritance during the testator's lifetime by various contractual devices such as antenuptial or postnuptial agreements, will contracts, life insurance, as well as by various property arrangements .... Paradoxically, all states but one provide the disinherited minor child - who had no choice concerning his existence and who is unable to provide for himself - with no direct protection from disinheritance. ${ }^{332}$

Thus, not only has the law of succession already carved out exceptions for family members, but the policies underlying the protections afforded spouses apply with equal (if not more) force to extending those protections to children.

Additionally, the existing law of succession protects some who are not even members of the testator's family - specifically creditors. One of the essential functions of probate law is to protect creditors by requiring payment of debts, ${ }^{333}$ and those debts are to be paid even before property is distributed to the decedent's heirs. As Blackstone said, "it is [the executor's] business first of all to see whether there is a sufficient fund left to pay the debts of the testator: the rule of equity being, that a man must be just, before he is permitted to be generous[.]"334 Thus, just as the law of succession protects spouses, it likewise protects creditors due in large part to the fact that "[t]he nonpayment of a decedent's debts, including the ability to circumvent creditors at death, would impose harm on others and increase the costs of financing during life. $"{ }^{\prime 35}$

Beyond simply providing an illustration of how testamentary freedom is not absolute, the law's treatment of creditors calls into question why a testator's obligation to support his or her children is not counted as a debt that survives the testator's death. After all, "[s]urely a parent is just as responsible for his child's existence as he is for the debts he incurs." ${ }^{336}$ While the parent is living, the law seems to agree. ${ }^{337}$ Indeed, the law

332. Brashier, Protecting the Child, supra note 16, at 12-13 (footnotes omitted).

333. See SITKOFF \& DUKEMINIER, supra note 111, at 44 (including "protect[ing] creditors by providing a procedure for payment of the decedent's debts" as one of the "three core functions" of probate).

334. 2 William BLACKSTONE, COMMENTARIES 512.

335. Kelly, supra note 35, at 1163.

336. Brashier, Protecting the Child, supra note 16, at 5 n.21.

337. See supra notes 272-273 and accompanying text. 
imposes upon parents an affirmative duty to support their dependent children, and that is true whether the dependency stems from the child's minority or "the adult child [who] is so mentally or physically disabled that he [or she] cannot support himself or herself." 338 Upon death, however, the testator parent can disinherit the dependent child, shifting the obligation of support to the state. ${ }^{339}$ Thus, just as allowing testators to avoid traditional debts would push those costs off onto society, so too does permitting testators to use death as a means of avoiding financial obligations to their children. Although some states do enforce a child support order against the estate of deceased parent, ${ }^{340}$ such protections only benefit those children who received such an order while the parent was living. Additionally, minor children cannot secure such orders on their own but are dependent upon another adult to obtain it for them. ${ }^{341}$ Thus, given their inability to protect themselves, minor children have even greater need for protections than do creditors.

Finally, the law of succession has not only carved out exceptions for certain individuals, but also for testamentary schemes that violate certain public policies. ${ }^{342}$ As noted earlier, the current list includes illegal activity, racial restrictions, and provisions designed to encourage divorce or separation - each of which would produce harmful externalities. ${ }^{343}$ State laws requiring parents to support their children and, at the same time, refrain from harming them are likewise designed to avoid harmful externalities, including the desire to keep children from becoming wards of the state and, perhaps even more so, to safeguard the health of civilization's future adults. ${ }^{344}$ As noted sociologist W.J. Goode explains,

The earliest moral and ethical writings suggest that a society loses its strength if people fail in their family obligations .... [P]hilosophers, reformers, and religions, as well as secular leaders, have throughout history been at least implicitly aware of the importance of family patterns as a central element in the social structure. ${ }^{345}$

338. Penney v. Penney, 785 So. 2d 376, 378 (Ala. Civ. App. 2000) (citing Beavers v. Beavers, 717 So. 2d 373 (Ala. Civ. App. 1997)).

339. See supra section I.A.; see also Asadorian, supra note 22, at 122 (noting that the obligation to support one's children "is one of the few financial obligations that appears to disappear at death").

340. See supra note 119 and accompanying text.

341. See BRASHIER, INHERITANCE LAW, supra note 132, at 110 (pointing out that "someone must take an affirmative step on behalf of the child to obtain a support agreement or decrees since the young child is unable to make these demands herself" (emphasis added)).

342. See Kelly, supra note 35, at 1162 (listing exceptions).

343. See supra note 74 and accompanying text.

344. See supra notes 228-231 and accompanying text.

345. W.J. Goode, The FAmily 1-2 (1964). 
Thus, the proposal at hand would merely require states to recognize that the list of public policies that limit testamentary freedom should be expanded to include the existing policies designed to safeguard children vis-à-vis their parents. To add to that list testamentary provisions that operate as parental abuse or neglect would not only be consistent with the purposes behind the public policy exception to testamentary freedom but would also make the law of succession consistent with all the other areas of law that do recognize the state's parens patriae authority to protect American children from harm. The law's continuing refusal to do otherwise - all in the name of preserving testamentary freedom-is simply without justification.

In sum, the evolving American family has created situations in which children are now more than ever at risk of being disinherited, including those children who are particularly vulnerable to the harms of disinheritance. For that reason, the law requires some mechanism through which courts, pursuant to their parens patriae obligations, can protect those for whom disinheritance would amount to parental abuse or neglect. The solution is not, as other countries have done, to outlaw all child disinheritance given that there does exist some important policy rationales supporting the rights of parents to disinherit their children. Instead, the law requires a more tailored approach-one that permits the courts to intervene where necessary to protect those most in need without unduly limiting testamentary freedom. What follows is a suggested approach to how a court might use its inherent parens patriae authority to craft just such a rule.

\section{INCORPORATING PARENS PATRIAE INTO THE LAW OF DISINHERITANCE}

Within the law of domestic relations, it is undisputed that the right to direct the upbringing of one's children must sometimes yield to the state's interest as parens patriae. ${ }^{346}$ It is the position of this Article that so too

\footnotetext{
346. Under the Fifth and Fourteenth Amendments, parents do possess a fundamental right to direct the upbringing of their children - a right that can be traced to two Supreme Court opinions in the 1920s. See Pierce v. Society of Sisters, 268 U.S. 510 (1925); Meyer v. Nebraska, 262 U.S. 390 (1923). Interestingly enough, the Court in both cases ruled that the state had unconstitutionally interfered with parental rights. Nothing in those opinions, however, suggests that this parental right is subject to strict scrutiny. Kyle Still, Comment, Smith's Hybrid Rights Doctrine and the Pierce Right: An Unintelligent Design, 85 N.C. L. REV. 385, 396 (2006) ("Furthermore, as in Meyer, the Court in Pierce used the language of rational basis, [and as such,] . . . Meyer and Pierce are distinct from cases dealing with other fundamental rights, which generally are treated with strict scrutiny."). Indeed, by 1944, the Court would state that "[a]cting to guard the general interest in youth's well being, [sic] the state as parens patriae may restrict the parent's control by requiring school attendance, regulating or prohibiting the child's labor, and in many other ways." Prince v. Massachusetts, 321 U.S. 158, 166 (1944) (footnotes omitted). For a longer discussion of the constitutional tension between parental
} 
must the right to disinherit one's children yield when that disinheritance would operate as a form of child abuse or neglect. In such instances, judges should employ their inherent parens patriae authority and refuse to give effect to the parent's attempt to disinherit the child. The theory being that courts cannot allow parental actions that harm the child, which in the disinheritance context includes withholding necessary parental support as well as perpetuating a pattern of child abuse. The remainder of this Part discusses the basic contours of such an exception, how it would apply to the three categories of vulnerable child heirs, and responses to some of the objections this proposal is likely to engender.

\section{A. The Basic Approach}

Under this proposal, a child would have to satisfy three basic requirements in order to set aside a parent's attempt at disinheritance. First, the child would have to establish that he or she qualifies as either a minor child, an adult child who remains dependent upon his or her parents as a result of disability, or an adult child who was abused by the testator parent during the child's minority. As explained earlier, the proposal limits the class of children to these three in an attempt to preserve the testamentary freedom of parents yet, at the same time, carve out protections for those children who stand to suffer the most harm as a result of being disinherited. ${ }^{347}$

Second, the child would have to establish that the testamentary document does in fact disinherit the child. In instances where the parent affirmatively states that the child is to receive nothing, this requirement will pose little difficulty. Some parents, however, may be tempted to bequeath the child some token amount in an attempt to thwart the child's ability to successfully challenge the bequest. Accordingly, in this context, "disinherit" would also have to encompass situations where the amount the parent left the child is so small as to, in effect, qualify as a disinheritance. Two possibilities exist for how states might make such a determination. The first is simply to compare the value of what the parent did bequeath the child to what the child would have inherited had the parent died intestate. Any deviation below a certain percentage set by the state would then count as a disinheritance. Second, for vulnerable child heirs for whom the parent had a continuing duty of support, the state might

rights and parens patriae, see Michael J. Higdon, The Quasi-Parent Conundrum, 90 U. COLO. L. REV. 941, 979 (2019).

347. See supra section III.A. The doctrine of parens patriae, of course, protects not only children but all vulnerable citizens. Id. Accordingly, although this proposal is limited to those who qualify as the testator's legal children, states might over time decide to expand this proposal to other dependents, such as informally adopted children or aging parents. 
borrow from its approach to child support determinations and establish guidelines for calculating the amount of support that parents, upon their death, owe vulnerable child heirs. ${ }^{348}$ Anything below that amount would then be considered a disinheritance.

Finally, even if disinherited, the vulnerable child heir would still have to show that the disinheritance constitutes abuse or neglect. To prevail under this requirement, both minor children and also adult children who remain dependent upon the testator parent would have to establish that the parent has failed to otherwise discharge the duty of support owed the child. For instance, the parent might have done so by way of an inter vivos trust or gift. Additionally, states might continue to allow disinheritance if the testator bequeathed a sufficient amount of property to the child's other parent so long as that parent was subject to an affirmative duty to provide for the child in question. ${ }^{349}$ In some circumstances, courts might even take into account whether someone other than the testator parent had already provided for the child to such an extent that, at the time the testator dies, disinheritance would not jeopardize the vulnerable child's interests. For example, a grandparent or other relative might have already set up a sizable trust fund that fully satisfies the child's needs.

Of course, for courts to engage in an analysis of this sort, they may potentially have to consider extrinsic evidence, which could be problematic given that some states have been reluctant to look beyond the four-corners of a testamentary document to ascertain the testator's intent. ${ }^{350}$ To remedy that problem, states need only adopt a rule that allows courts to consider extrinsic evidence regarding whether a testator parent had otherwise satisfied their support obligation to a vulnerable child heir. States have taken a similar approach in the past regarding pretermission statutes, which are designed to protect children from accidental disinheritance. ${ }^{351}$ Even if states were unwilling to go that far, however, they could simply require that testators who wish to disinherit a vulnerable child heir must include an explanation in the testamentary document as to

348. See generally Molly E. Christy, Unjust and Inequitable: An Argument Against Strict Application of the Child Support Guidelines When the Obligor Parent and Child Live in Different Countries, 20 QUINNIPIAC PROB. L.J. 260, 262-67 (2007) (discussing the evolution and current operation of child support guidelines in the United States).

349. Other scholars who have proposed changes to the American approach to disinheritance have included similar provisions. See, e.g., Batts, supra note 1, at 1258 (proposing that "if the testator has provided for all children by means other than estate assets so that the children would receive their equivalent share by these nonestate means, the proposal would be satisfied").

350. See Kristine S. Knaplund, Postmortem Conception and A Father's Last Will, 46 ARIZ. L. REV. 91, 114 (2004) ("Because the best evidence of the testator's intent, the testator, is dead when the will is probated, courts have 'traditionally been reluctant to allow extrinsic evidence in interpreting wills.") (internal quotations omitted).

351. See, e.g., In re Estate of Richardson, 50 P.3d 584, 587 (Okla. Civ. App. 2002) (“[E]xtrinsic evidence may be admitted to show an heir was unintentionally omitted."). 
why the parent felt he or she had otherwise sufficiently provided for the child. For those testators who neglect to include that explanation or whose explanation fails to convince the court that the disinheritance would not amount to abuse or neglect, only then would the court refuse to enforce the attempted disinheritance.

When it comes to adult survivors of abuse, however, the abuse and neglect determination would require some additional showings. After all, the theory of recovery there is not so much that the parent is neglecting their duty of support to a dependent child, but that the court cannot, pursuant to its role as parens patriae, endorse an attempt at disinheritance that is in furtherance of abuse inflicted upon the child by the testator during the child's minority. Thus, at a minimum, adult survivors of child abuse would need to demonstrate more than the mere fact they were an abused child whose parent had failed to provide for them at death. First, they would likely need to demonstrate that the abuse began during their minority given that state policies of protecting children from abuse are aimed primarily at minor children. ${ }^{352}$ Next, the adult survivor would need to establish that this abuse occurred at the hands of the testator and also that the attempt at disinheritance is in furtherance of or a product of that abuse. Because of the time that has likely elapsed since the abuse occurred as well as the difficulties in even defining "abuse," ${ }^{353}$ it could be quite difficult to prove these elements. Nonetheless, proof problems alone should not be a basis for denying even the possibility of recovery to those whose childhood abuse continues into adulthood in the form of adult disinheritance. ${ }^{354}$

352. Additionally, "[d] espite the high incidence of child abuse, the majority of adult children [are] not abused." Lara Q. Plaisance, Will You Still ... When I'm Sixty-Four: Adult Children's Legal Obligations to Aging Parents, 21 J. AM. ACAD. MATRIM. LAW. 245, 266-67 (2008). This is not to say that states cannot protect children from disinheritance when they were abused by the testator as an adult. Just as many states have passed laws preventing perpetrators of elder abuse from inheriting from their victims, states could pass similar legislation for testators who abused their adult children. See generally Nina A. Kohn, Elder (In)justice: A Critique of the Criminalization of Elder Abuse, 49 AM. CRIM. L. REV. 1, 2 (2012). The point here is merely that a court may have difficult imposing such a rule given the degree to which parens patriae authorizes court intervention on behalf of minor children. See generally Lisa C. Dumond, Comment, The Undeserving Heir: Domestic Elder Abuser's Right to Inherit, 23 QUINNIPIAC PROB. L.J. 214 (2010).

353. See Donald N. Duquette, Child Protection Legal Process: Comparing the United States and Great Britain, 54 U. PITT. L. REV. 239, 241 (1992) ("[The definition of what actually constitutes child abuse and neglect is not clear within a particular country, much less uniform from one society to another." (emphasis omitted)).

354. Consider for instance the tort of intentional infliction of emotional distress. Most agree that it is quite hard for a plaintiff to establish the necessary elements, yet nonetheless the cause of action remains available. See Alan Calnan \& Andrew E. Taslitz, Defusing Bomb-Blast Terrorism: A Legal Survey of Technological and Regulatory Alternatives, 67 TENN. L. REV. 177, 231 (1999) (noting that IIED is "very difficult to prove").

A somewhat related example can be found in how courts have dealt with claims by adult children who allege that their parents sexually abused them as children. As a result of repressed memories, many adult 
Even in the case of a former abused child, the question arises as to whether one can ever know for certain why a testator disinherited a child. After all, the disinheritance could have been for some other reason. Few testators would be so bold as to openly declare that their intent was to heap additional abuse on their children. One solution would simply be to employ a rebuttable presumption that might operate as follows: if a child can establish by clear and convincing evidence that he or she was abused by the testator parent during the child's minority, then the court will presume that the disinheritance was a product of that abuse, giving the proponent of the will an opportunity to then rebut that presumption with evidence that the disinheritance was for some unrelated reason. Assuming the child could satisfy all the three requirements - for instance, that the child qualifies as a vulnerable child heir, that the testator did disinherit the child, and that the disinheritance would amount to abuse or neglect - the court would not enforce the disinheritance.

As to the remedy, the simplest solution would be to award the child an intestate share. The law already offers a similar remedy, under the pretermission statutes, for those children who were inadvertently excluded from a will. Consider, for instance, the New Hampshire pretermission statute which provides that "Every child ... not named or referred to in his will, and who is not a devisee or legatee, shall be entitled to the same portion of the estate, real and personal, as he would be if the deceased were intestate." ${ }^{355}$ Or, as noted earlier, the states could establish support guidelines, like those used for determining child support, to help calculate the appropriate remedy for dependent children whose parents attempted to disinherit them. ${ }^{356}$ Just as child support guidelines take into account a number of considerations, so too would guidelines for this purpose. Variables to consider would include the child's age, the size of the estate, the number of other surviving children, and whether the testator died leaving a spouse. A final benefit to establishing such guidelines would be - in contrast to the family maintenance approach adopted by a

children do not even become aware of the abuse until much later in life when the statute of limitations might have elapsed. See generally Jodi Leibowitz, Criminal Statutes of Limitations: An Obstacle to the Prosecution and Punishment of Child Sexual Abuse, 25 CARDOZO L. REV. 907 (2003). In response, many states have tolled the statute of limitations in such instances recognizing that

the doctrine of delayed discovery may be applied in a case where plaintiff can establish lack of memory of tortious acts due to psychological repression which took place before plaintiff attained the age of majority, and which caused plaintiff to forget the facts of the acts of abuse until a date subsequent to which the complaint is timely filed.

Mary D. v. John D., 264 Cal. Rptr. 633, 639 (Ct. App. 1989), superseded by 788 P.2d 1155 (Cal. 1990).

355. N.H. Rev. Stat. Ann. § 551:10 (2020).

356. See Christy, supra note 348 and accompanying text; see also Taite, supra note 31, at 330 (noting how, when it comes to child support, America follows "the continuity-of-expendeture model," which "operates from either the percentage-of-obligor-income formula or the income-shares formula"). 
number of countries - the greater certainty and consistency it would afford to those entitled to recovery. ${ }^{357}$

\section{B. Potential Objections}

The foregoing suggestions are an attempt to delineate the broad contours of how a parens patriae exception to testamentary freedom might operate - one aimed at protecting the state's most vulnerable children from the harms of disinheritance. Were courts to implement such an exception, however, it is unreasonable to expect they could do so without some degree of opposition and objection. The chief criticism would likely be the degree to which such an approach would curtail testamentary freedom. As explained earlier, however, that impact is relatively minor and, at the same time, is consistent with other limitations the law has imposed on testamentary freedom. ${ }^{358}$ Nonetheless, even if that overall objection can be overcome, the implementation of such an exception is likely to give rise to even further questions, and it is the goal of this section to both identify what they might be as well as provide some potential responses.

One of the initial concerns that would need to be addressed relates to entitlement. Specifically, if children are not entitled to inherit from their parents, how can one justify an approach whereby courts refuse to enforce certain attempts at disinheritance? There are two potential responses. One would be to simply characterize this proposal as abolishing the precept that children are never entitled to an inheritance. The impact of the proposal, after all, would be that vulnerable child heirs are in fact entitled to inherit some amount from their parents absent some indication that the parent has otherwise discharged his or her obligation to the child. The goal of this Article, however, is to take a position that is a bit more nuanced: namely, even if children are in no way entitled to an inheritance from their parents, the state still cannot be complicit in any attempt by parents to abuse or neglect their children, and that includes certain attempts at disinheritance. Thus, this proposal does not really change the landscape of entitlement vis-á-vis disinheritance, but more precisely, it delineates when the state can and cannot, as parens patriae, play a role in enforcing that disinheritance.

A second objection that would likely need to be addressed is the extent to which this proposal would invite litigation. Disinheritance is disruptive enough when it comes to family harmony, but a will contest brought by a

357. See supra notes $170-176$ and accompanying text.

358. See supra section III.B. 
family member can be even more damaging. ${ }^{359}$ The proposal outlined herein would certainly encourage some disinherited heirs to bring actions in which they allege a number of things, including that whatever the parent did bequeath them was inadequate to fulfill the parent's support obligations, that the child is disabled and thus incapable of being disinherited, or perhaps most damaging, that the parent abused the child during the child's minority and is thus precluded from now disinheriting the adult child. No doubt some such claims would be frivolous, perhaps brought by disgruntled children solely as means of forcing a settlement with the estate. ${ }^{360}$ The first response to such concerns would be that, as detailed earlier, the exception is limited to three classes of children individuals who find themselves in fairly specific circumstances. ${ }^{361}$ As such, concerns about this exception to testamentary freedom giving rise to rampant litigation are likely unwarranted. Second, regardless of how much litigation a proposal such as this might generate, the reality is that any exception to testamentary freedom will invite litigation. Nonetheless, the law of succession already contains a number of exceptions, each of which have no doubt resulted in a number of divisive, perhaps even frivolous, lawsuits. ${ }^{362}$ Those exceptions exist, however, because the law has decided that the protections they offer outweigh such concerns. It is the position of this Article that, at the very least, the need for an exception that protects vulnerable child heirs from disinheritance rises to that same level.

Finally, there are the questions of whether this proposal goes far enough and, relatedly, whether it is somewhat myopic to focus so heavily on the financial harms of disinheritance. After all, being disinherited by one's parent is likely harmful regardless of the child's age, needs, or past

359. See Jeffrey P. Rosenfeld, Will Contests: Legacies of Aging and Social Change, in INHERITANCE AND WEALTH IN AMERICA 173, 174 (Robert K. Miller Jr. \& Stephen J. McNamee, eds. 2013) ("Will contests are socially and economically significant events. ... They can rupture and realign the social fabric of families and keep millions of dollars tied up in litigation for years ... [They] often involve large estates and can create decades of ill will in families.").

360. Or by the parents of those disgruntled heirs. See Brashier, Modern Family, supra note 18, at 173 ("A vengeful ex-spouse or ex-lover of the testator would be tempted to expose the testator's dirty laundry in the process of ensuring that her disinherited child by the testator received a satisfactory maintenance award.").

361. See supra section III.B.1.

362. For instance, disgruntled heirs can bring claims in which they attempt to prove that the testator lacked capacity or suffered from an insane delusion. See generally Adam J. Hirsch, Testation and the Mind, 74 WASH. \& LEE L. REV. 285, 286 (2017) (discussing insane delusion and capacity). Disgruntled heirs are also currently permitted to try and block a bequest to a third party on the basis that the third party exerted undue influence on the testator, or, in some states, committed elder abuse. Id.; see also, e.g., CAL. PROB. CODE $§ 259(\mathrm{a})(1)-(4)$ (West 2011) (stating that a person is deemed to have predeceased a decedent if it is proven that the person is liable for physical abuse of the elder adult). Any of these claims could involve unseemly facts that could further disrupt family harmony. 
history with the parent. ${ }^{363}$ And in many instances that harm may be more psychological than financial. One might object to this Article's proposal as giving too short a shrift to the psychological harm of disinheritancea particularly poignant criticism given that, under parens patriae, courts attempt to protect children from a number of harms including emotional abuse. Thus, perhaps one might argue that an approach like the forced heirship or family maintenance statutes is more appropriate given that they have the ability to protect all children. ${ }^{364}$ That objection is a more difficult one to resolve because extending the exception that far would represent a dramatic shift to America's long-standing rules regarding succession. ${ }^{365}$ Of course, tradition alone should not dictate current practice. ${ }^{366}$ Nonetheless, it is the position of this Article that the American approach to permitting child disinheritance is grounded upon important considerations, and a wholesome overthrow of those principles might not be in anyone's best interest. As Daniel Kelly has persuasively argued:

[D]isregarding donative intent may harm the donees themselves. In response to the possibility of legal intervention, a donor may alter her behavior. For example, if $D$ believes courts will not facilitate her intent, $D$ may consume more during life. If $D$ owns less property at death, the donees will inherit less wealth. Moreover, if $D$ anticipates that a court will intervene and ignore her intent, $D$ may alter her disposition by making a gift during life, choosing different donees, or forgoing the gift entirely. ${ }^{367}$

Thus, the proposal outlined above is believed to safeguard those concerns and yet, at the same time, provide sorely needed protection for America's growing population of particularly vulnerable children.

\section{CONCLUSION}

The rights of children to receive support from their parents and to be shielded from parental abuse must supersede the law's solicitude for "the dead hand." 368 Although the United States has always permitted testators to disinherit their children-regardless of age, need, or justificationsociety has changed and with it so too must the law of succession. By permitting any parent to disinherit any child, the United States has

363. See Taite, supra note 31 , at 345 ("Because disinheriting a child is generally perceived as an unnatural act, children may view this act as a betrayal.").

364. See supra section I.B.

365. See supra section I.A.

366. See, e.g., Obergefell v. Hodges, 576 U.S. _, 135 S. Ct. 2584, 2598 (2015) (stating that we must respect "our history and learn[] from it without allowing the past alone to rule the present").

367. Kelly, supra note 35, at 1129.

368. See, e.g., J.E. PENnER, The IDEA OF Property IN LAW 99 (1997) ("Though we appear to respect the intentions of the dead, we may be fools to do so."). 
expressed a willingness to put a certain percentage of children at risk of suffering abuse or neglect at the hands of their testator parent. However, with the evolving American family - particularly the increase in divorce, remarriage, and cohabitation - that possibility has increased drastically, and thus the likelihood of such abuse and neglect has now grown. Thus, the United States can no longer ignore the fact that, when it comes to the ability of a testator to disinherit his or her children, wholesale testamentary freedom simply cannot coexist with the state's parens patriae responsibility to protect its most vulnerable citizens.

Recognizing the role that the doctrine of parens patriae plays in this context not only illuminates the dangers and limitations of the current approach, but also offers a solution - one that more effectively balances the need for some degree of testamentary freedom with the duty of the state to protect needy children from abuse and neglect. This Article has attempted to sketch out the broad contours of what a parens patriae exception to testamentary freedom might look like. However, regardless of the precise form it takes, it is imperative that states begin to implement some solution to the problem of child disinheritance. To instead ignore this growing threat to American children would not only continue to elevate the property interests of the dead over those of the living, but would in fact give the dead hand even greater power, bestowing upon it a right that no living person would ever be permitted to exercise - the right to intentionally abuse or neglect his or her children. 